\title{
Nitrogen and carbon cycling in the North Sea and exchange with the North Atlantic-A model study, Part II: Carbon budget and fluxes
}

\author{
Wilfried Kühn ${ }^{\text {a,* }}$, Johannes Pätsch ${ }^{\text {a }}$, Helmuth Thomas ${ }^{\mathrm{b}, \mathrm{c}}$, Alberto V. Borges ${ }^{\mathrm{d}}$, \\ Laure-Sophie Schiettecatte ${ }^{\mathrm{d}}$, Yann Bozec ${ }^{\mathrm{e}}$, A.E. Friederike Prowe ${ }^{\mathrm{f}}$ \\ a Institut für Meereskunde der Universität Hamburg, Bundesstr. 53, D-20146 Hamburg, Germany \\ ${ }^{\mathrm{b}}$ Dalhousie University, Halifax, Canada

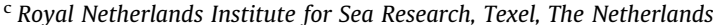 \\ d Chemical Oceanography Unit, University of Liège, Liège, Belgium \\ e Station Biologique de Roscoff, F-29682 Roscoff, France \\ ${ }^{\mathrm{f}}$ Leibniz-Institut für Meereswissenschaften Kiel, Germany
}

\section{A R T I C L E I N F O}

\section{Article history:}

Received 3 July 2009

Received in revised form

11 June 2010

Accepted 1 July 2010

Available online 11 July 2010

Keywords:

Ecosystem modeling

ECOHAM

HAMSOM

North Sea

Carbon budget

North Atlantic Oscillation

Continental shelf pump

$\mathrm{CO}_{2}$ uptake

Net ecosystem production

River loads

Stratification

\begin{abstract}
A B S T R A C T
The 3-d coupled physical-biogeochemical model ECOHAM (version 3) was applied to the NorthwestEuropean Shelf $\left(47^{\circ} 41^{\prime}-63^{\circ} 53^{\prime} \mathrm{N}, 15^{\circ} 5^{\prime} \mathrm{W}-13^{\circ} 55^{\prime} \mathrm{E}\right)$ for the years 1993-1996. Carbon fluxes were calculated for the years 1995 and 1996 for the inner shelf region, the North Sea $\left(511,725 \mathrm{~km}^{2}\right)$. This period was chosen because it corresponds to a shift from a very high winter-time North Atlantic Oscillation Index (NAOI) in 1994/1995, to an extremely low one in 1995/1996, with consequences for the North Sea physics and biogeochemistry. During the first half of 1996, the observed mean SST was about $1{ }^{\circ} \mathrm{C}$ lower than in 1995; in the southern part of the North Sea the difference was even larger (up to $3{ }^{\circ} \mathrm{C}$ ). Due to a different wind regime, the normally prevailing anti-clockwise circulation, as found in winter 1995, was replaced by more complicated circulation patterns in winter 1996. Decreased precipitation over the drainage area of the continental rivers led to a reduction in the total (inorganic and organic) riverine carbon load to the North Sea from $476 \mathrm{Gmol} \mathrm{C} \mathrm{yr}^{-1}$ in 1995 to $340 \mathrm{Gmol} \mathrm{C} \mathrm{yr}^{-1}$ in 1996. In addition, the North Sea took up $503 \mathrm{Gmol} \mathrm{C} \mathrm{yr}^{-1}$ of $\mathrm{CO}_{2}$ from the atmosphere. According to our calculations, the North Sea was a sink for atmospheric $\mathrm{CO}_{2}$, at a rate of $0.98 \mathrm{~mol} \mathrm{C} \mathrm{m}^{-2} \mathrm{yr}^{-1}$, for both years. The North Sea is divided into two sub-systems: the shallow southern North Sea (SNS; $190,765 \mathrm{~km}^{2}$ ) and the deeper northern North Sea (NNS; 320,960 $\mathrm{km}^{2}$ ). According to our findings the SNS is a net-autotrophic system (net ecosystem production $\mathrm{NEP}>0$ ) but released $\mathrm{CO}_{2}$ to the atmosphere: $159 \mathrm{Gmol} \mathrm{C} \mathrm{yr}^{-1}$ in 1995 and $59 \mathrm{Gmol} \mathrm{C} \mathrm{yr}^{-1}$ in 1996. There, the temperature-driven release of $\mathrm{CO}_{2}$ outcompetes the biological $\mathrm{CO}_{2}$ drawdown. In the NNS, where respiratory processes

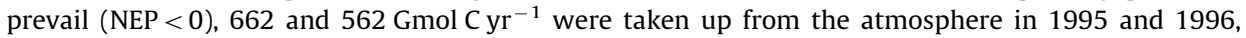
respectively. Stratification separates the productive, upper layer from the deeper layers of the water column where respiration/remineralization takes place. Duration and stability of the stratification are determined by the meteorological conditions, in relation to the NAO. Our results suggest that this mechanism controlling the nutrient supply to the upper layer in the northern and central North Sea has a larger impact on the carbon fluxes than changes in lateral transport due to NAOI variations. The North Sea as a whole imports organic carbon and exports inorganic carbon across the outer boundaries, and was found to be net-heterotrophic, more markedly in 1996 than in 1995.
\end{abstract}

(c) 2010 Elsevier Ltd. All rights reserved.

\section{Introduction}

Continental shelves play a key role in the global cycling of biogeochemically essential elements. Based on observations in the East China Sea, Tsunogai et al. (1999) speculated about global consequences if all shelves, like the East China Sea, would act as a

\footnotetext{
* Corresponding author. Tel.: +494042838 6628.

E-mail address: paetsch@ifm.uni-hamburg.de (J. Pätsch).
}

sink for atmospheric carbon dioxide and as a source of carbon for the open ocean. The concept of the "continental shelf pump" since has been confirmed also for the North Sea (Thomas et al., 2004; Bozec et al., 2005). This concept describes physical or biological mechanisms by which atmospheric $\mathrm{CO}_{2}$ is transported via the continental shelf sea into the deeper adjacent ocean. For this process to be effective several prerequisites of the marine shelf system are required: strong biological activity, partly sustained by anthropogenic nutrient inputs, and efficient exchange with the adjacent ocean. In the case of the North Sea, as part of the 
Northwest-European Shelf, the seasonal stratification of the northern part decouples production and decomposition of organic matter within the upper and the lower water column, respectively, thus enhancing the pump efficiency (Thomas et al., 2004).

Carbon-related measurements in the North Sea started in the late 1980s (Pegler and Kempe, 1988; Kempe and Pegler, 1991; Hoppema, 1991) and have been continued in the following years. In most cases the southern North Sea and its coastal areas were in the focus of these observations (Frankignoulle et al., 1996; Borges and Frankignoulle, 1999, 2002, 2003; Frankignoulle and Borges, 2001; Schiettecatte et al., 2006, 2007; Borges et al., 2008). Regional model studies also concentrated on the Southern Bight and the Belgian coastal zone (Gypens et al., 2004, 2009; Borges and Gypens, 2010). Thomas et al. (2005a) were the first to calculate an observation-based carbon budget for the whole North Sea covering a complete annual cycle.

In order to overcome some of the required assumptions for the observation-based budget, such as climatological water exchange with the North Atlantic or averaged dissolved inorganic carbon (DIC) concentrations at the boundaries, the ecosystem model ECOHAM was applied to the Northwest-European Shelf. With this tool, Prowe et al. (2009) provided insight into the controlling mechanisms for the partial pressure of $\mathrm{CO}_{2}\left(\mathrm{pCO}_{2}\right)$ for the two biogeochemical regions of the North Sea, the shallower permanently mixed southern and the seasonally stratified northern parts.

Pätsch and Kühn (2008; hereafter PK1) introduced the ecosystem model ECOHAM and discussed the nitrogen fluxes for the years 1995 and 1996. Although it was found that riverine nutrient inputs were larger in 1995, the nitrogen assimilation, i.e. the Redfield primary production, of the whole North Sea was nearly the same for both years. The key to this seemingly counterintuitive result was the different behavior of the southern and the northern North Sea. For the former, primary production is clearly related to riverine nutrient loads. In the latter, the supply of inorganic nitrogen into the euphotic zone from deeper layers (and much less the river input) controls the primary production. The supply of inorganic nitrogen to surface layers is directly linked to the stability of stratification of the water column. The higher sea surface temperature (SST) in 1995 compared to 1996 induced a stronger, more stable stratification in 1995. Consequently, during summer 1996, the inorganic nitrogen flux into the upper layer was larger and led to higher annual net primary production (ANPP) in the northern North Sea, compensating for the decrease of the primary production in the southern North Sea due to the lower riverine nitrogen loads.

To be consistent with PK1, in the present work we also have chosen the mid-nineties because they exhibit a shift from a very high winter-time North Atlantic Oscillation Index (NAOI) in 1994/ 1995 , to an extremely low one in 1995/1996. According to Dippner (1997), the mean winter SST in NAOI-low years is generally lower than in years with high NAOI. Indeed, Loewe (1996) observed an extremely low SST in the North Sea during the first half of the year 1996. In NAOI-high years westerly winter winds dominate, whereas in NAOI-low years winds from easterly directions prevail.

Less precipitation over the drainage area of the continental rivers led not only to a reduction in the total riverine nitrogen input to the North Sea from $76 \mathrm{Gmol} \mathrm{N} \mathrm{yr}^{-1}$ in 1995 to $52 \mathrm{Gmol}$ $\mathrm{N} \mathrm{yr}^{-1}$ in 1996, but also to a corresponding decrease of the riverine carbon loads from $476 \mathrm{Gmol} \mathrm{C} \mathrm{yr}^{-1}$ in 1995 to $340 \mathrm{Gmol}$ $\mathrm{C} \mathrm{yr}^{-1}$ in 1996.

In the present paper, we present the first model-derived annual carbon budgets for the inner shelf region, i.e., for the North Sea $\left(511,725 \mathrm{~km}^{2}\right)$ and its sub-regions, for the years 1995 and 1996. We compare simulated concentrations of near-surface dissolved inorganic carbon (DIC) with observations made in
2001/2002 (Thomas et al., 2004, Bozec et al., 2006). We investigate whether the consideration of decoupling of carbon from nitrogen uptake by phytoplankton is necessary for a realistic simulation of the DIC observations and quantify the $\mathrm{CO}_{2}$ air-sea flux for the two years. We show that the drastic shift in the NAOI, the dominant climate mode over the North Atlantic, has consequences for the North Sea biogeochemistry and in particular for the air-sea flux of $\mathrm{CO}_{2}$ and its control by physical and biological processes.

\section{Model setup}

The details of the ecosystem model ECOHAM were described in PK1. Here, we only present the processes, which are of importance for the simulation of the carbon cycle.

The model area, comprising the greater part of the NorthwestEuropean Shelf, is shown in Fig. 1. This figure also depicts the boundaries of the North Sea used for calculating the carbon budgets. Additionally, we defined a boundary between southern and northern North Sea along $55.4^{\circ} \mathrm{N}$, i.e., north of the Dogger Bank.

\subsection{Non-Redfield ratios, excess production and calcium carbonate formation}

Because the model encompasses both the carbon and the nitrogen cycle, the selection of the molar $\mathrm{C}: \mathrm{N}$ ratios used is important. We chose fixed, but different C:N ratios for the different biotic compartments: The Redfield ratio $\mathrm{C}: \mathrm{N}=6.625$ for phytoplankton, $\mathrm{C}: \mathrm{N}=5.5$ for zooplankton, and $\mathrm{C}: \mathrm{N}=4.0$ for bacteria. The biogenic compartments 'dissolved organic matter' and 'detritus', on the other hand, have free-floating C: $N$ ratios. In particular, the $\mathrm{C}: \mathrm{N}$ ratio of particulate organic matter increases due to preferential nitrogen remineralization during sinking (Thomas et al., 1999; Pätsch et al., 2002). In order to maintain the prescribed molar $\mathrm{C}: \mathrm{N}$ ratios within the zooplankton and bacteria compartments additional carbon or nitrogen fluxes were introduced (see PK1-Appendix).

In addition to the so-called Redfield primary production $\left(\mathrm{NPP}_{\text {red }}\right)$ which is determined by the availability of nitrogen, the model allows for 'excess' or 'overflow' (Fogg, 1983) production $\left(\mathrm{NPP}_{\mathrm{exc}}\right)$ or, as Toggweiler (1993) called it, carbon overconsumption, defined as carbon fixation by photosynthesis during periods when surface layers are depleted in bioavailable nitrogen (Thomas et al., 1999). This additionally fixed carbon is released in the form of dissolved or colloidal extracellular carbohydrates which tend to coagulate forming transparent exopolymer particles (TEP) (Engel, 2002; Schartau et al., 2007). In the model the excess carbon is immediately channeled into the pool of slowly degradable semi-labile dissolved organic carbon, which is eventually metabolized by the bacteria (on a time scale of 9 months). Thus, the model differentiates between 'normal' exudation by phytoplankton, the result of which is labile dissolved organic matter with Redfield composition (Fogg, 1983), and an excess exudation of semi-labile organic carbon with higher $\mathrm{C}: \mathrm{N}$ ratios.

The total net primary production (NPP) is defined as

$\mathrm{NPP}=\mathrm{NPP}_{\text {red }}+\mathrm{NPP}_{\mathrm{exc}}$

Given the uncertainty in the order of magnitude of the overflow production in the North Sea we introduced a scaling factor $\left(f_{\text {exc }}\right)$ which allows us to vary the strength of NPP exc: For $f_{\text {exc }}=0.0$, only Redfield production takes place; for $f_{\text {exc }}=1.0$, maximum (only light-limited) overflow production is possible. For this simulation we chose $f_{\text {exc }}=0.5$; when allowing for Redfield 


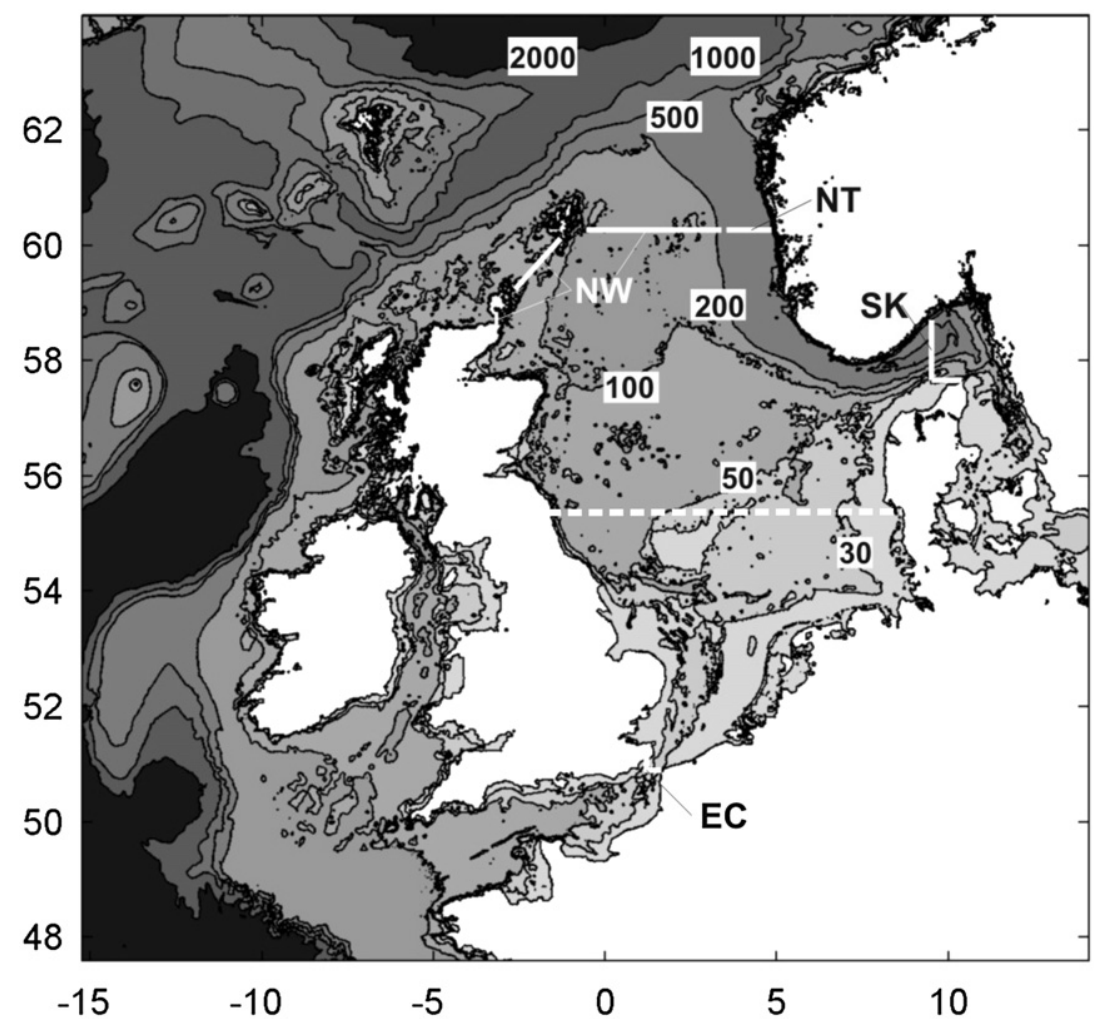

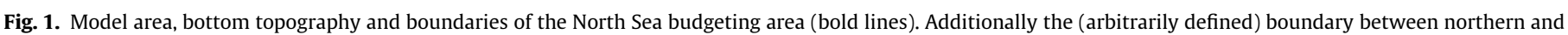
southern North Sea is indicated (dashed line). The outer boundaries are denoted as NW—north-western boundary, SK—Skagerrak, and EC—English Channel.

production only $\left(f_{\text {exc }}=0.0\right.$ ), the near-surface DIC concentrations during summer remained higher than observed. Thus, we could avoid limitations introduced in an earlier study (Prowe et al., 2009) by prescribing different values of $f_{\text {exc }}$ for the SNS and the NNS (for a more detailed discussion see Section 4.3).

The model also simulates the production of calcium carbonate $\left(\mathrm{CaCO}_{3}\right)$, but in a very simplified way. The phytoplankton produces calcite whenever it produces organic matter $(\mathrm{OM})$, the corresponding molar production ratio is $\mathrm{CaCO}_{3}-\mathrm{C}: \mathrm{OM}-\mathrm{C}=1: 70$, according to a lower estimate of the ratio between carbonate production and primary production in the ocean (Chung et al., 2003; Langer, 2008). This approach obviously neglects the specific seasonality and the regional differences of the $\mathrm{CaCO}_{3}$ production by coccolithophorids, but supplies a carbonate production on the Northwest-European shelf which is in the range of global estimates. The carbonate shells become part of the fast-sinking detritus and are dissolved while sinking through the water column and in the sediment layer. The dissolution rate is a function of the carbonate oversaturation (see PK1-Appendix).

\subsection{External sources, initial and boundary conditions}

In addition to high inorganic and organic nitrogen loads (see: PK1) rivers discharge considerable amounts of inorganic and organic carbon into the North Sea (Thomas et al., 2005a). According to the well known fact that large parts of this organic carbon load are retained/degraded in the estuaries (Raymond and Bauer, 2000; Wiegner and Seitzinger, 2001; Abril et al., 2002) and based on observations that the remaining DOC and at least half of the POC can be viewed as refractory (J. Hartmann, pers. comm.) we concluded that using a riverine TOC input of $760 \mathrm{Gmol} \mathrm{C} \mathrm{yr}^{-1}$ (RWS, 1992) would be much too high. We therefore assumed only $10 \%$ of the total organic riverine carbon load to be bioavailable, adding it to the slowly sinking detritus pool. The value of $76 \mathrm{Gmol} \mathrm{C} \mathrm{yr}^{-1}$ agrees quite well with the DOC/POC input used by Thomas et al. (2005a).

At the open boundaries (outside the North Sea region) we prescribed depth-dependent monthly mean values of DIC concentrations and total alkalinity (TALK) values supplied by the Max-Planck-Institute for Meteorology, Hamburg (U. Mikolajewicz, pers. comm.). These model data were obtained from the biogeochemical model HAMOCC5 (Maier-Reimer, 1993; MaierReimer et al., 2005) embedded in the physical ocean model of the Max-Planck-Institute for Meteorology (MPIOM, Marsland et al., 2003). The MPIOM was forced with NCEP atmospheric reanalysis data (Kalnay et al., 1996) for 1948-2007 and $\mathrm{pCO}_{2}$ in the atmosphere. The grid configuration was designed to optimally resolve the North Atlantic and the Northwest-European shelf.

For initialization and in case of TALK for restoring, observed data (CANOBA project; Thomas et al., 2004) were used for the area of the North Sea. As these data were taken in 2001/2002 we reduced the observed DIC concentrations by $9 \mu \mathrm{mol} \mathrm{kg}{ }^{-1}$. This corresponds to an annual increase by $1 \mu \mathrm{mol} \mathrm{kg}{ }^{-1} \mathrm{yr}^{-1}$, which reflects the rise of atmospheric $\mathrm{CO}_{2}$ concentrations by approximately $1.6 \mathrm{ppm} \mathrm{yr}^{-1}$ at a Revelle factor of 11 (Thomas et al., 2008). Boundary conditions of nitrate were derived from the World Ocean Atlas 2001 (Conkright et al., 2002). The TALK fields for the North Sea were interpolated to daily values at each grid point; these values were used for restoring the simulated TALK data with a relaxation time scale of two weeks.

Using prescribed alkalinity concentrations and dynamically varying DIC concentrations also takes into account the shift in the carbonate system due to biological activities: DIC uptake (primary production) increases the $\mathrm{pH}$ and DIC release (respiration) decreases the $\mathrm{pH}$.

Other effects, which would be handled by a dynamic approach of alkalinity, are ignored by the present model configuration. With 


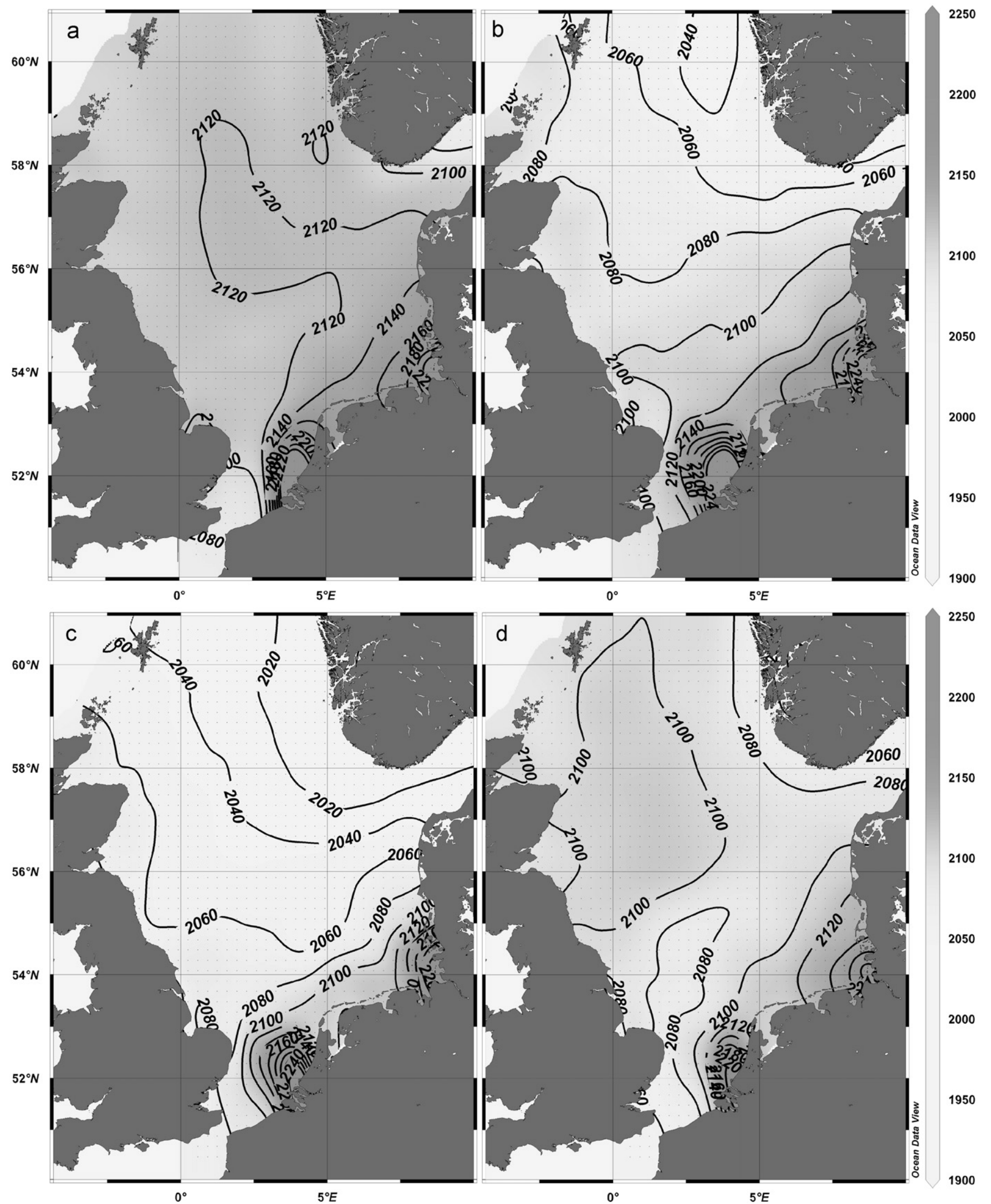

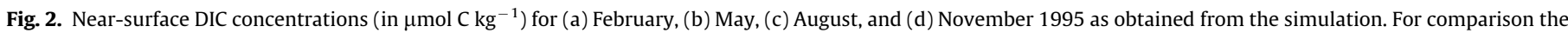
observed DIC concentrations for (e) February 2002, (f) May 2002, (g) August/September 2001, and (h) November 2001 are shown. 

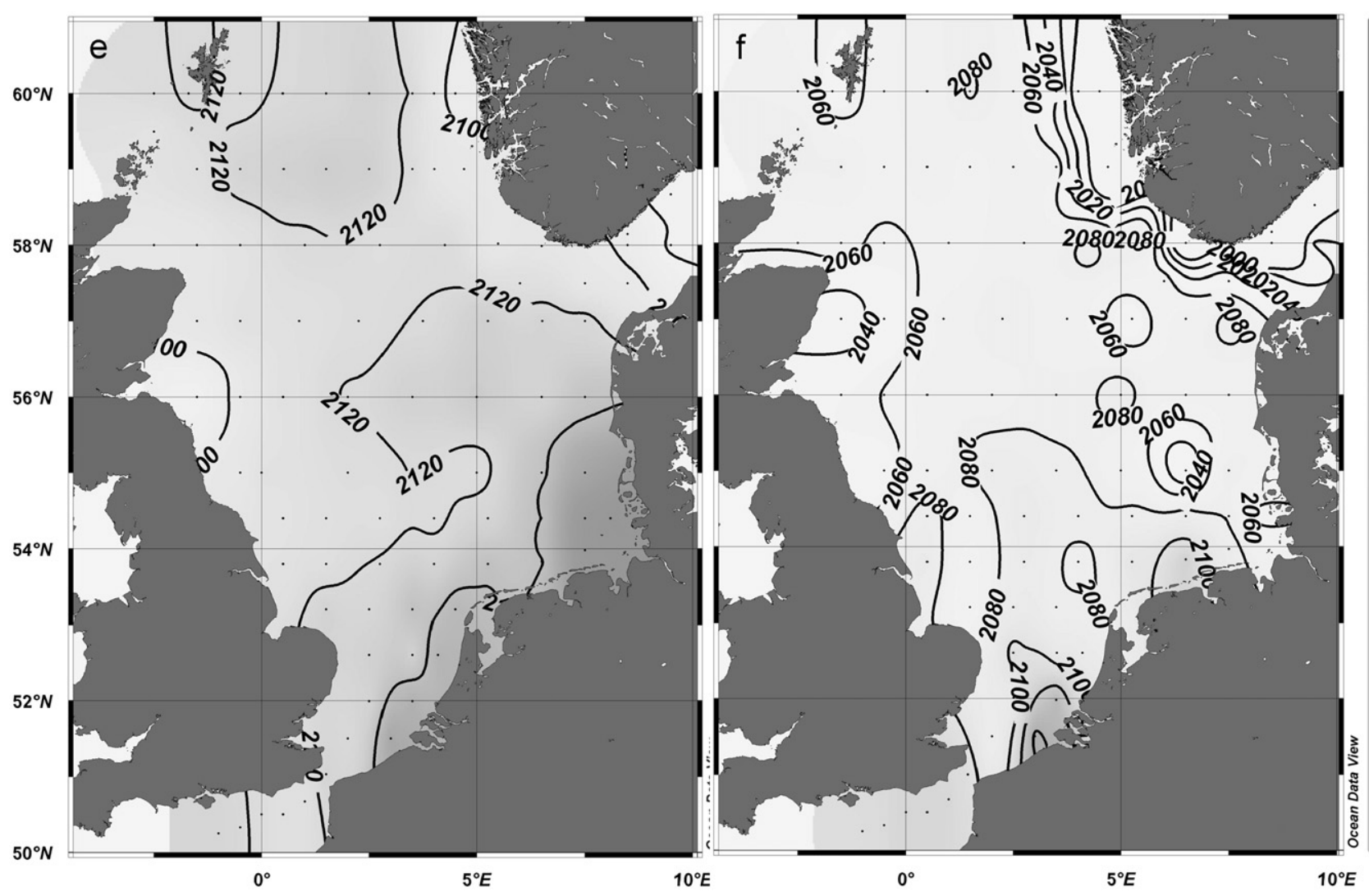

2250

2200

2150

2100

2050

2000

1950

1900

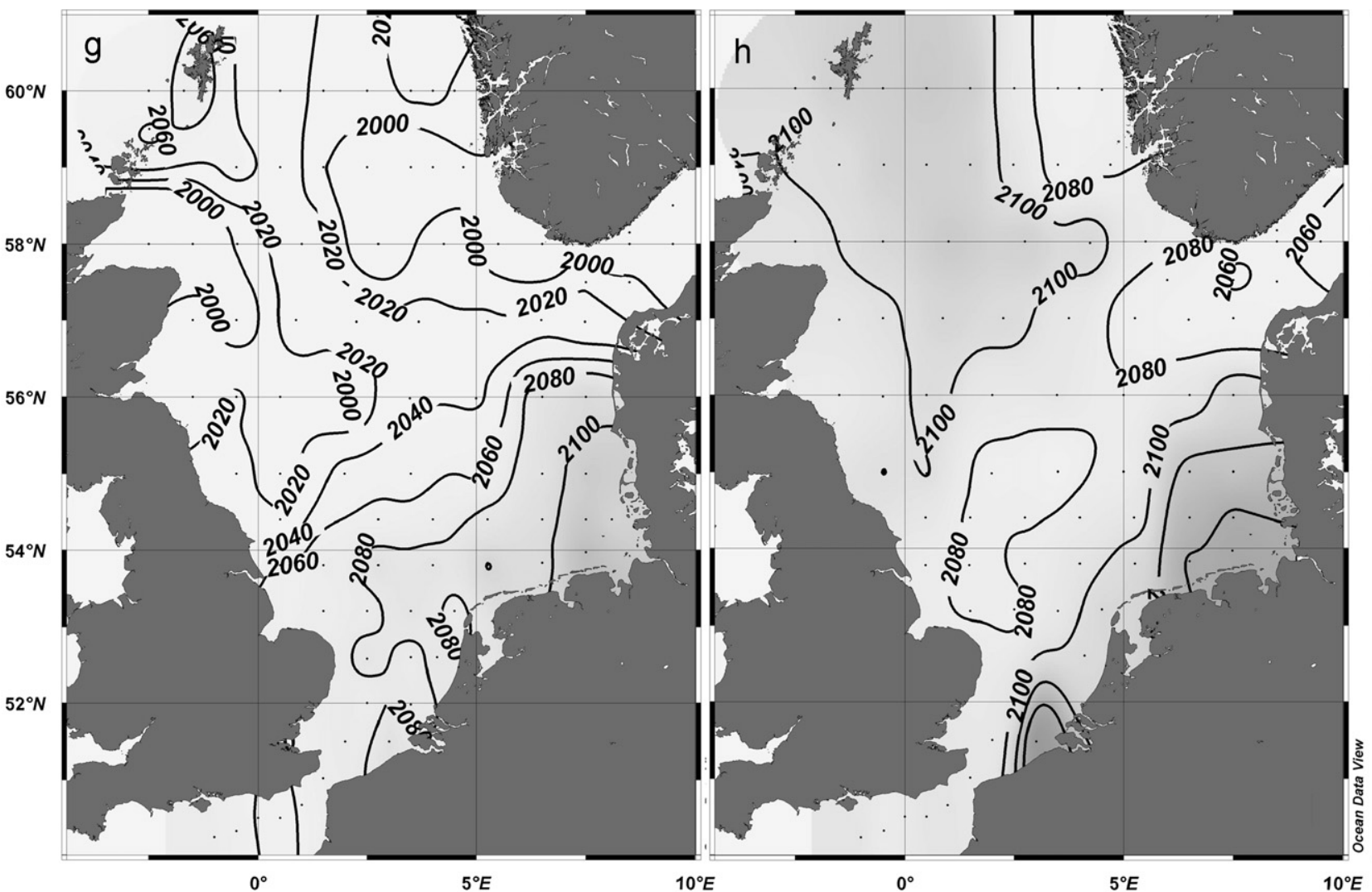

2250

2200

2150

2100

2050

2000

1950

1900

Fig. 2. (Continued)

our diagnostic approach we neglect the increase of alkalinity during primary production by nitrate assimilation and ammonia release during degradation of organic material. Likewise, we ignore effects of decreasing TALK during ammonia uptake and nitrification. However, DIC variations (e.g. during nitrate assimilation) are larger than nitrate variations by at least a factor of 
6.625 (Redfield ratio). Moreover, nitrate produced by nitrification does not play a role for the TALK budget, because the decrease of TALK due to nitrification (two units) is compensated by a corresponding increase during nitrate assimilation (one unit) and ammonium release during degradation (one unit). Modifications of TALK by calcification and calcite dissolution are not explicit in the model.

\subsection{The air-sea flux}

The air-sea flux of $\mathrm{CO}_{2}$ was calculated according to the formula:

$F\left(\mathrm{CO}_{2}\right)=k\left(\mathrm{pCO}_{2}^{\mathrm{air}}-\mathrm{pCO}_{2}^{\mathrm{wat}}\right)$,

where $\mathrm{pCO}_{2}^{\text {air }}$ denotes the prescribed partial pressure of $\mathrm{CO}_{2}$ in the atmosphere, $\mathrm{pCO}_{2}^{\text {wat }}$ the partial pressure of $\mathrm{CO}_{2}$ in the near-surface water and $k$ the wind-dependent gas transfer or piston velocity. We used the empiric expression derived by Wanninkhof (1992) for the gas transfer velocity. According to a sensitivity study, the use of other parameterizations of $k$ (Wanninkhof and McGillis, 1999; Nightingale et al., 2000) changed the resulting annual net air-sea flux of $\mathrm{CO}_{2}$ by less than $5 \%$. The annual time series for the partial pressure of atmospheric $\mathrm{CO}_{2}$ was calculated based on the CANOBA data set taking into account an annual increase of $1.6 \mu \mathrm{atm} \mathrm{yr}^{-1}$. The $\mathrm{pCO}_{2}^{\text {wat }}$ was calculated from the water temperature, salinity, the DIC concentration and TALK by applying the equilibrium equations of the carbonate system using the carbonic acid constants according to Mehrbach et al. (1973) as refit by Dickson and Millero (1987).

\subsection{The benthic layer}

Sinking organic and inorganic $\left(\mathrm{CaCO}_{3}\right)$ material is captured in a bottom layer below the deepest grid cell, where it is differentially remineralized, i.e. with different remineralization rates for organic carbon and nitrogen. The carbonate is dissolved with the saturation-dependent dissolution rate of calcite valid for the corresponding water depth (see PK1-Appendix).

\section{Results}

\subsection{DIC concentrations}

Having validated the model with regard to nitrate and chlorophyll (PK1), the most important model state variable to compare with observations is the DIC concentration. Fig. $2 \mathrm{a}-\mathrm{d}$ shows the regional distribution of the simulated near-surface DIC concentrations, for February, May, August, and November 1995. For comparison, the corresponding DIC concentrations measured in the CANOBA project during the years 2001/2002 are shown (Fig. 2e-h; Thomas et al., 2004; Bozec et al., 2006), because data for the mid-nineties were not available.

The observations show a clear seasonal pattern: high DIC concentrations in winter (February) and low DIC concentrations in late summer (August/September). This seasonal signal is reproduced by the simulations. The observed regional distribution patterns-e.g. highest concentrations mostly in the southern North Sea, particularly in the German Bight and along the Belgian, Dutch, and German continental coast-are also captured by the

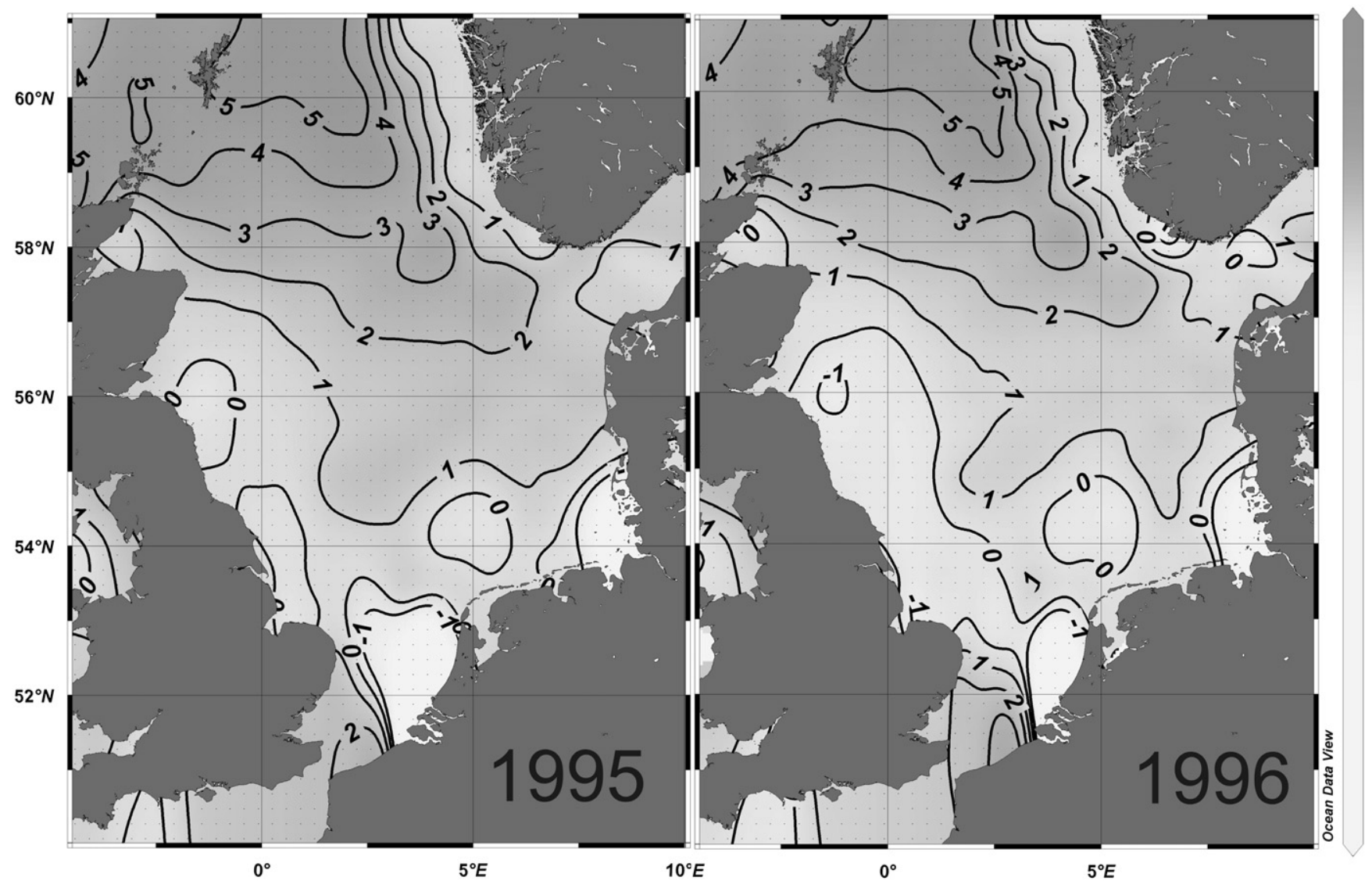

Fig. 3. Regional distribution of the annual air-sea flux of $\mathrm{CO}_{2}$ (in mol $\mathrm{C} \mathrm{m}^{-2} \mathrm{yr}^{-1}$ ) for 1995 and 1996 as obtained from the simulation. 

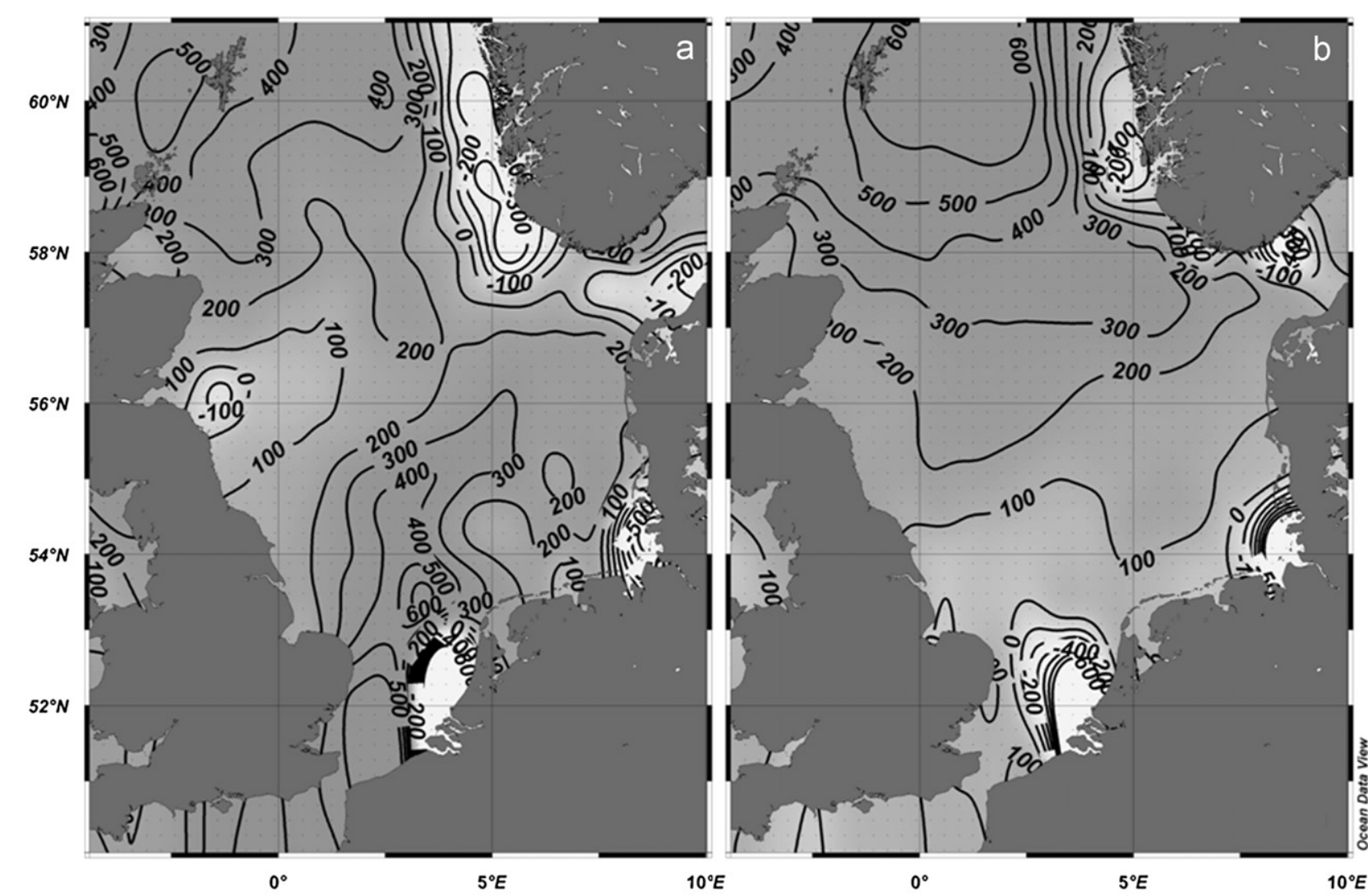

1000

500

0

$-500$

$-1000$
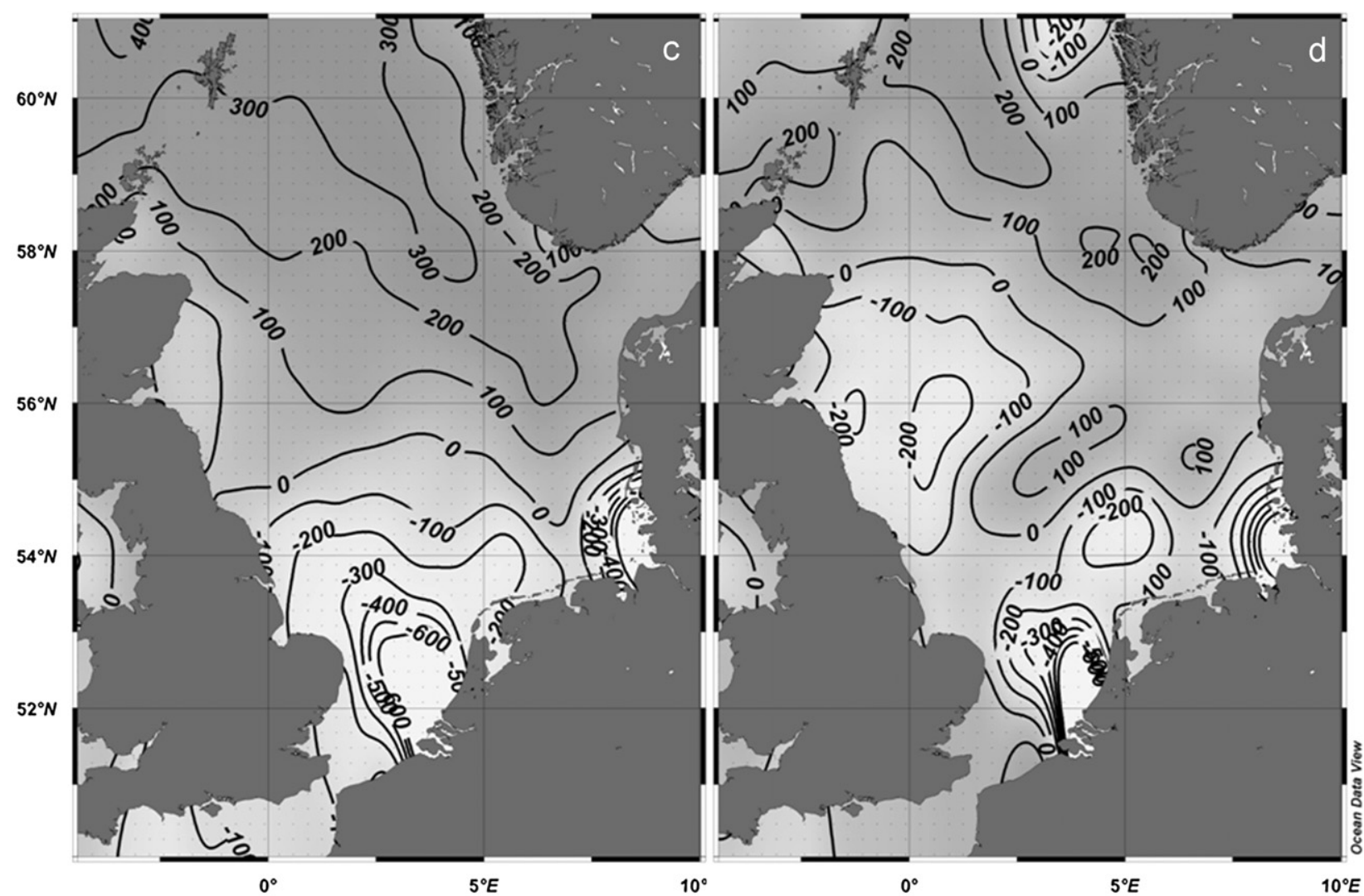

1000

500

0

Fig. 4. Seasonal variability of the simulated air-sea flux of $\mathrm{CO}_{2}$ (in mmol C m${ }^{-2}$ month $^{-1}$ ) for 1995: (a) February, (b) May, (c) August, and (d) November.

model results. A closer look, however, reveals several deviations between observed and simulated near-surface DIC concentrations, mainly during spring and summer. For May 1995 the simulated DIC concentrations are higher than those observed in May 2002, the difference being highest along the Norwegian coast. In late summer, the modeled DIC concentrations in the 
northern North Sea are also higher than the observed values. Especially, the very low DIC values observed in the Skagerrak and off the British coast are not reproduced in the simulation. Striking are the very high simulated concentrations off the Rhine and Elbe rivers mouths. It should, however, be stressed that we are comparing observations and model data from different years; interannual variability of river runoff might play an important role in causing parts of these differences (Radach and Pätsch, 2007). Generally, the quality of the model results depends strongly on the availability and quality of the outer sources of DIC (riverine inputs, input from the Baltic and from the North Atlantic).

\subsection{Fluxes and budgets}

\subsubsection{Air-sea $\mathrm{CO}_{2}$ fluxes}

In Fig. 3, the annual air-sea flux of $\mathrm{CO}_{2}$ is shown for the years 1995 and 1996. For the whole North Sea, the annual $\mathrm{CO}_{2}$ sink amounts to $503 \mathrm{Gmol} \mathrm{C} \mathrm{yr}^{-1}$ or $0.98 \mathrm{~mol} \mathrm{C} \mathrm{m}^{-2} \mathrm{yr}^{-1}$ for both years. According to our model results, the greater part of the North Sea (about $70 \%$ of its area) is a net sink for atmospheric $\mathrm{CO}_{2}$. Along the British coast and north of the Frisian Islands we find weak source areas. Strong outgassing occurs in the plumes of the Rhine and Elbe rivers. This holds for both years; however, in 1996 the source off the British coast area is somewhat extended, but most of all, the sink in the central and southern North Sea is weakened, compared to 1995.

Thomas et al. (2004) estimated from their observations for $2001 / 2002$ an annual net $\mathrm{CO}_{2}$ uptake of about $1.4 \mathrm{~mol} \mathrm{C} \mathrm{m}^{-2}$ $\mathrm{yr}^{-1}$. Thus, from observations as well as from our model study the North Sea can be characterized as a sink for atmospheric $\mathrm{CO}_{2}$. The carbon taken up can only be exported to the neighboring North Atlantic or accumulate in organic or inorganic form within the North Sea. We address these questions in the section on the carbon budget.

The air-sea flux of $\mathrm{CO}_{2}$ has a pronounced seasonal cycle. Fig. 4 shows the simulated monthly $\mathrm{CO}_{2}$ fluxes for the months February, May, August, and November 1995. As a persistent pattern, during all months small regions with intense outgassing such as the inner German Bight (Elbe outlet) and north of the river Rhine outlet is to be seen. This was not observed during the CANOBA cruises in 2001/2002 (Thomas et al., 2004). Possible explanations for this deviation are a) that the large DIC and TOC loads of both rivers were not sufficiently diluted in the model and $b$ ) that the CANOBA sampling grid did not capture those river plumes close to the coast.

In late winter and in spring, we found nearly the whole North Sea to be a sink of $\mathrm{CO}_{2}$, whereas in summer and autumn mainly the southern and western parts of the North Sea released $\mathrm{CO}_{2}$ to the atmosphere. Compared with the observation-derived air-sea fluxes of $\mathrm{CO}_{2}$ (Fig. 5 in Thomas et al. (2005b), note that the fluxes given there have to be multiplied by a factor of 10 ), we find overall good correspondence as well in the order of magnitude as in the regional patterns. The main difference (besides the aforementioned river plumes) is that in February 2002 a large region in the central North Sea was a source of $\mathrm{CO}_{2}-$ in obvious contrast to our model results. The reason for this might be the difference in SST between 1995 and $2002\left(1-2{ }^{\circ} \mathrm{C}\right)$ : the warmer surface water in 2002 favored the outgassing of $\mathrm{CO}_{2}$.

In order to separate biological from physical/chemical controls on the air-sea $\mathrm{CO}_{2}$ flux, an additional simulation, the "no-biology run", was performed, where only hydrodynamic and chemical processes (carbonate chemistry) are simulated. Assuming as a first approximation a linear superposition of the physical/ chemical and the biological effects, we calculated the biologically mediated air-sea flux ( ASF $_{\text {bio }}$ ) by subtracting the purely physically/chemically controlled air-sea flux of the "no-biology run" $\left(\mathrm{ASF}_{\text {phys }}\right)$ from that of the standard run. The resulting $\mathrm{ASF}_{\mathrm{bio}}$ in 1996 is lower than the $\mathrm{ASF}_{\text {bio }}$ in 1995 by $260 \mathrm{Gmol} \mathrm{C} \mathrm{yr}^{-1}$ (Table 1), corresponding to a decline of the $\mathrm{CO}_{2}$ flux from 1.2 to $0.65 \mathrm{~mol} \mathrm{C} \mathrm{m}^{-2} \mathrm{yr}^{-1}$. This decrease occurs in both parts of the North Sea by almost the same amount, in the southern North Sea more or less due to a corresponding difference in the net ecosystem production (as discussed hereafter).

The annual cycle of the air-sea flux of $\mathrm{CO}_{2}$ is shown in Fig. 5 for both years, separately for the whole North Sea (Fig. 5a), the northern (NNS, Fig. 5b), and the southern North Sea (SNS, Fig. 5c), respectively. From these results some general patterns can be deduced:

1) The annual cycle is determined by a strong $\mathrm{CO}_{2}$ uptake by the NNS plus a weak uptake by the SNS during the first half of the year; in the second half of the year the uptake by the NNS is nearly compensated by $\mathrm{CO}_{2}$ outgassing in the SNS.

2 ) In both sub-regions the physics dominate the uptake during the first 3-4 months of the year, afterwards we note physically driven outgassing due to the annual cycle of the SST.

3) For the North Sea as a whole, the biology drives net uptake of $\mathrm{CO}_{2}$, in particular during May, June, and July. In autumn, biologically driven $\mathrm{CO}_{2}$ uptake is compensated by physically driven outgassing.

4) Without biological processes both the SNS and NNS would be a net source of $\mathrm{CO}_{2}$.

\subsubsection{Net primary production, net ecosystem production, heterotrophic respiration}

The most important fluxes characterizing the functioning of the ecosystem are the NPP (divided into the Redfield part, NPP ${ }_{\text {red }}$, and

Table 1

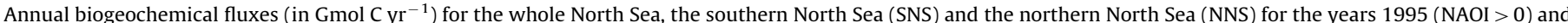

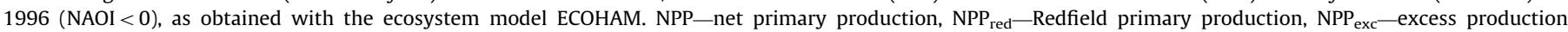

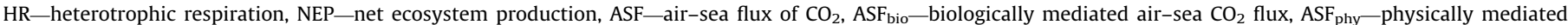
air-sea $\mathrm{CO}_{2}$ flux.

\begin{tabular}{|c|c|c|c|c|c|c|c|c|c|}
\hline \multirow[t]{2}{*}{ Flux } & \multicolumn{3}{|c|}{ North Sea } & \multicolumn{3}{|l|}{ SNS } & \multicolumn{3}{|l|}{ NNS } \\
\hline & 1995 & 1996 & 1996-1995 & 1995 & 1996 & 1996-1995 & 1995 & 1996 & 1996-1995 \\
\hline NPP & 9019 & 8870 & -149 & 3412 & 3129 & -283 & 5606 & 5741 & +135 \\
\hline NPP $_{\text {red }}$ & 7624 & 7645 & -21 & 3032 & 2803 & -229 & 4591 & 4841 & +250 \\
\hline $\mathbf{N P P}_{\text {exc }}$ & 1395 & 1225 & -170 & 380 & 326 & -54 & 1015 & 900 & -115 \\
\hline HR & 9067 & 9233 & +206 & 3317 & 3125 & -192 & 5750 & 6108 & +358 \\
\hline NEP & -48 & -363 & -315 & +95 & +4 & -91 & -144 & -368 & -224 \\
\hline ASF & +503 & +503 & 0 & -159 & -59 & +100 & +662 & +562 & -100 \\
\hline ASF $_{\text {bio }}$ & +594 & +334 & -260 & +136 & +23 & -113 & +458 & +311 & -147 \\
\hline ASF $_{\text {phy }}$ & -91 & +169 & +260 & -295 & -82 & +213 & +204 & +251 & +47 \\
\hline
\end{tabular}


the 'overflow' or 'excess' production NPP ${ }_{\text {exc }}$ ) and NEP defined as

$\mathrm{NEP}=\mathrm{GPP}-\mathrm{AR}-\mathrm{HR}=\mathrm{NPP}-\mathrm{HR}$,

where GPP is gross primary production, AR is autotrophic respiration and HR is heterotrophic respiration. Contributors to HR - in our model - are bacteria and zooplankton in the pelagic and the benthic remineralization. All these fluxes are given in Table 1 for 1995 and 1996.

For 1995, we obtain an NPP of $9019 \mathrm{Gmol} \mathrm{C} \mathrm{yr}^{-1}$, corresponding to $211 \mathrm{~g} \mathrm{C} \mathrm{m}^{-2} \mathrm{yr}^{-1}, 15 \%$ of this amount being NPP exc. The mean annual C:N ratio of the total NPP is 7.8. For 1996, the NPP amounts to $8870 \mathrm{Gmol} \mathrm{C} \mathrm{yr}^{-1}\left(208 \mathrm{~g} \mathrm{C} \mathrm{m}^{-2} \mathrm{yr}^{-1}\right)$ with a mean C:N ratio of 7.2. As can be seen from Table 1, this decrease of NPP of less than $2 \%$ compared to 1995 is due to a decrease of the overflow production, mainly in the NNS. At the same time, HR increased with the consequence of a drastic decrease of NEP from -48 to $-363 \mathrm{Gmol} \mathrm{C} \mathrm{yr}^{-1}$. That means, from 1995 to 1996 the trophic state of the North Sea became more net-heterotrophic. Yet, the annual net $\mathrm{CO}_{2}$ uptake from the atmosphere remained nearly constant during both years at $503 \mathrm{Gmol} \mathrm{C} \mathrm{yr}^{-1}$.

A negative NEP indicates that the biological $\mathrm{CO}_{2}$ release (due to $\mathrm{AR}$ and $\mathrm{HR}$ ) is larger than the $\mathrm{CO}_{2}$ uptake by GPP. At first sight, this should translate into outgassing of $\mathrm{CO}_{2}$ to the atmosphere. However, this can only happen if the $\mathrm{CO}_{2}$ is released into the surface layer and thus is able to escape into the atmosphere. In case of a strong and long-lasting stratification this might not a
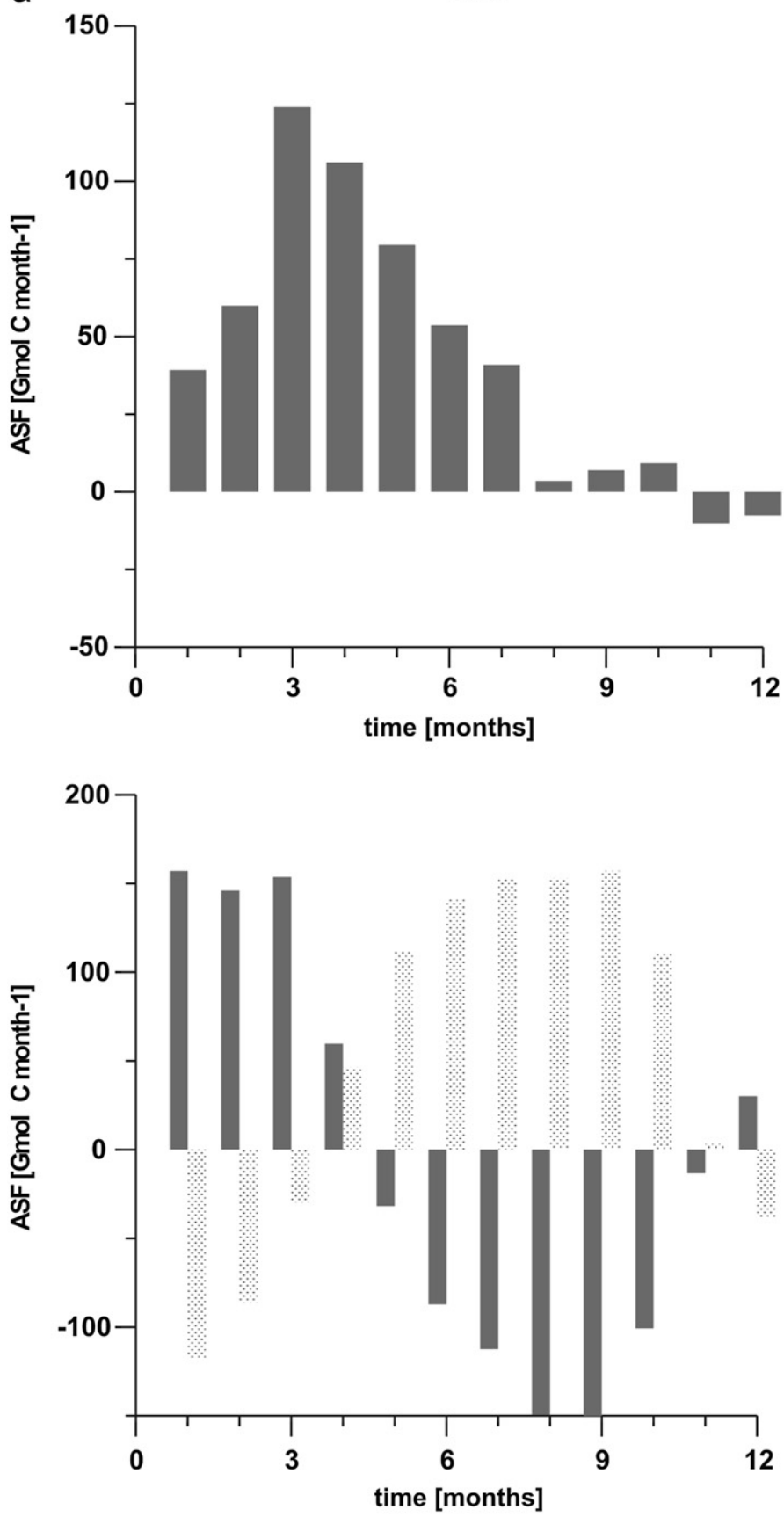

1996
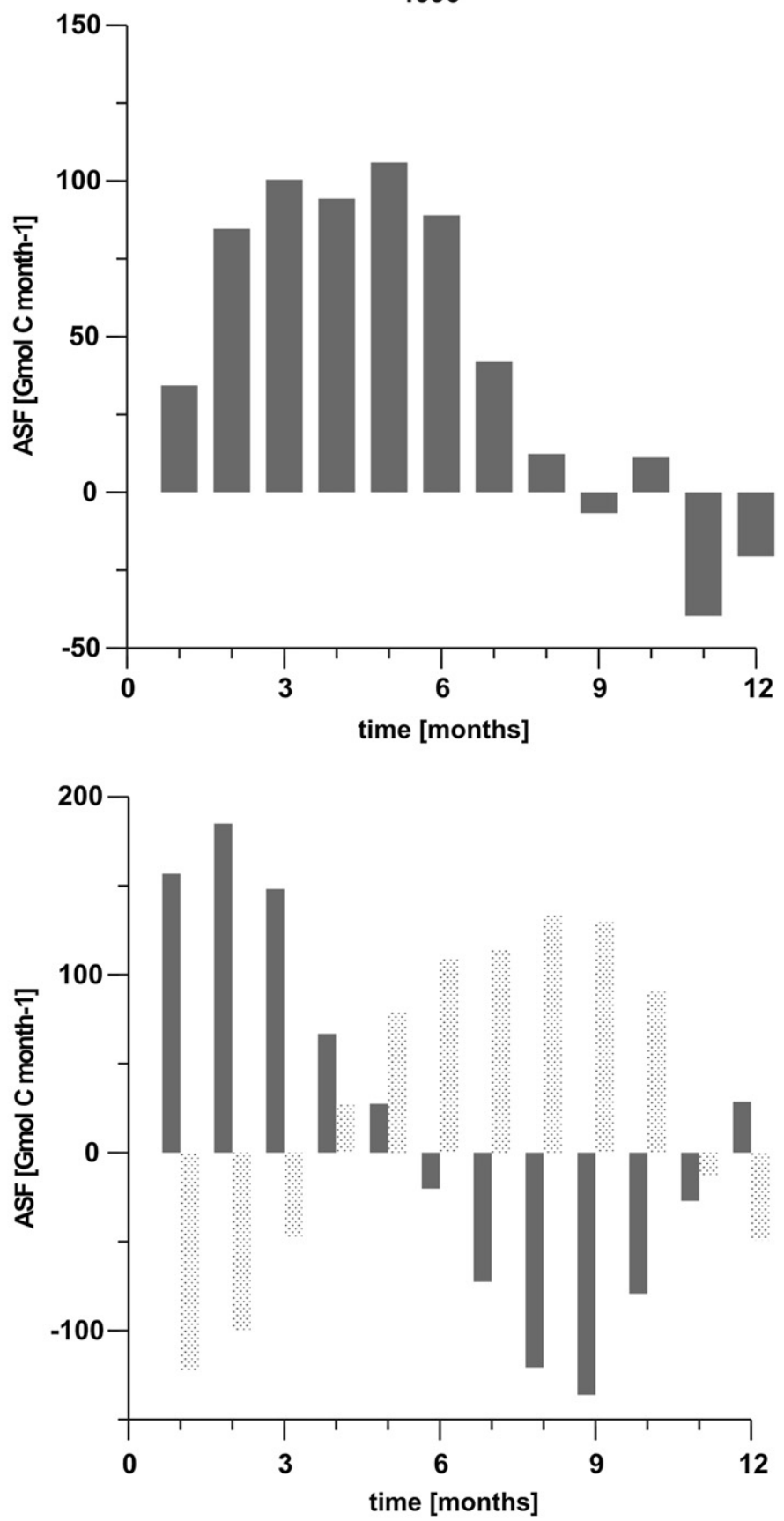

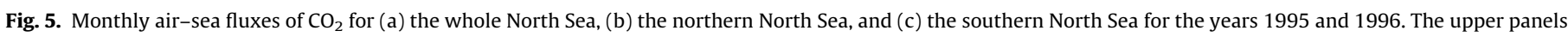

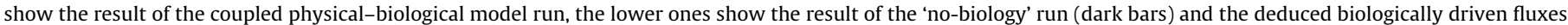
(light bars). Positive sign: influx, negative sign: efflux. 
b
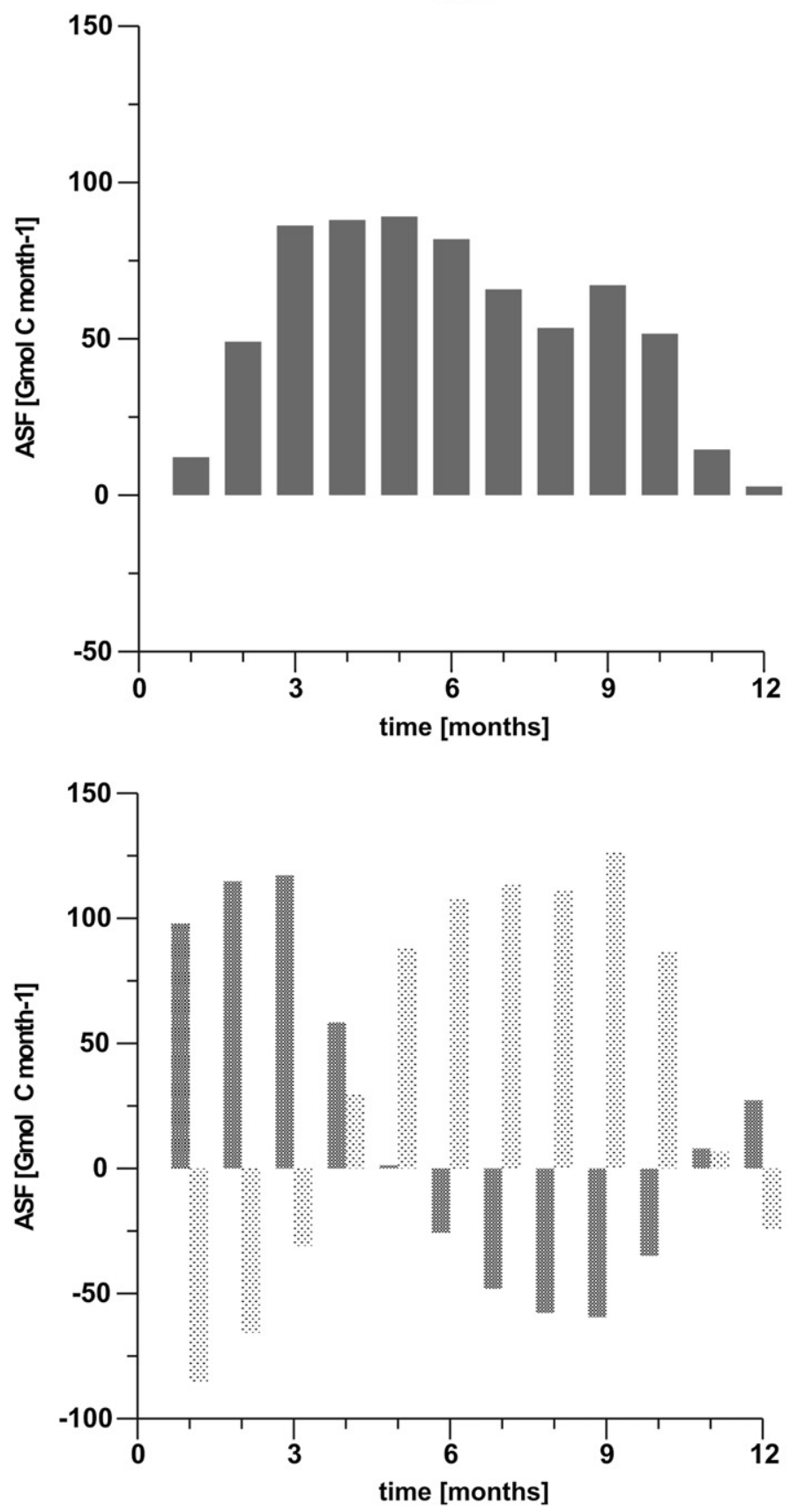

1996
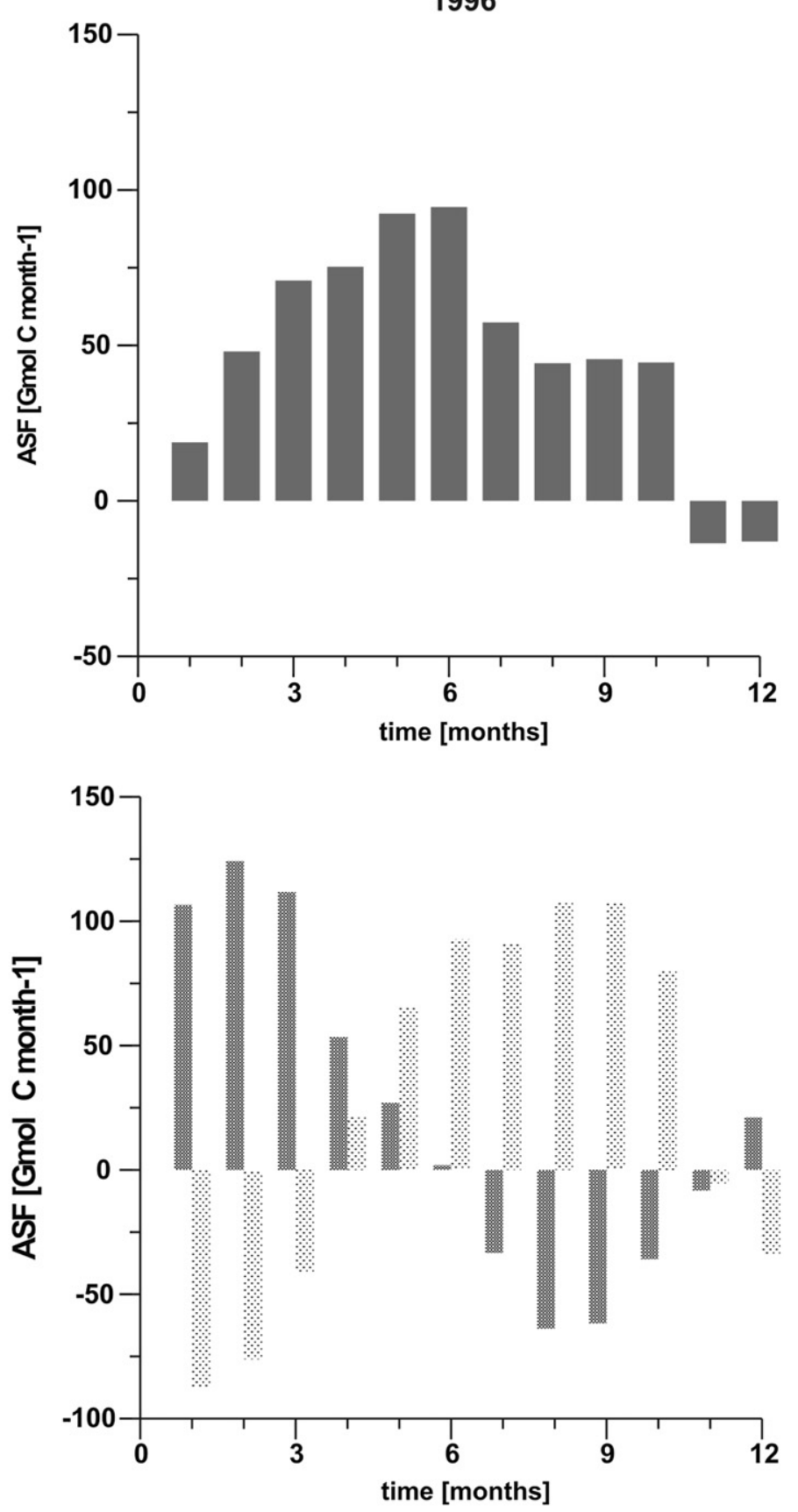

Fig. 5. (Continued)

happen. This means the air-sea $\mathrm{CO}_{2}$ flux is not only determined by the biological processes, but as well by the prevailing hydrodynamic conditions, mainly the SST and the mixing regime. This explains why for the northern North Sea the difference in $\mathrm{ASF}_{\mathrm{bio}}$

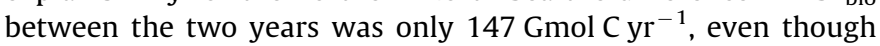
the NEP was more negative by $224 \mathrm{Gmol} \mathrm{C} \mathrm{yr}^{-1}$ in 1995 than in 1996. In the northern North Sea, a significant part of the HR took place without contact with surface waters (Bozec et al., 2006).

The processes leading to the decrease in NEP from 1995 to 1996 differ between NNS and SNS. On the one hand, there is a decline of the total NPP in 1996, due to a strong decrease of NPP in the SNS, which is only partially compensated by an increase of NPP in the NNS. On the other hand, there is an increase of the HR, predominantly in the NNS which is only partially compensated by a decrease of HR in the SNS. The regional increase in HR can be explained by the corresponding increase in $\mathrm{NPP}_{\text {red. }}$. However, while in the NNS, NPP red increased by $250 \mathrm{Gmol} \mathrm{C} \mathrm{yr}^{-1}, \mathrm{HR}$ increased by $358 \mathrm{Gmol} \mathrm{C} \mathrm{yr}^{-1}$ (Table 1). The question is whether this difference can be attributed to different residence times of subsurface waters in the NNS. These residence times are related to the strength of water (and thus carbon) export via the Norwegian Trench. While in 1995 with a high NAOI and a more pronounced anti-clockwise circulation (PK1-Fig. 3) the export of carbon via the deep Norwegian Trench was $110,654 \mathrm{Gmol} \mathrm{C} \mathrm{yr}^{-1}$, it was only $104,835 \mathrm{Gmol} \mathrm{C} \mathrm{yr}^{-1}$ in 1996. The water export was $1.60 \mathrm{~Sv}$ $\left(10^{6} \mathrm{~m}^{3} \mathrm{~s}^{-1}\right)$ in 1995 and $1.52 \mathrm{~Sv}$ in 1996 (Table 2). This could 

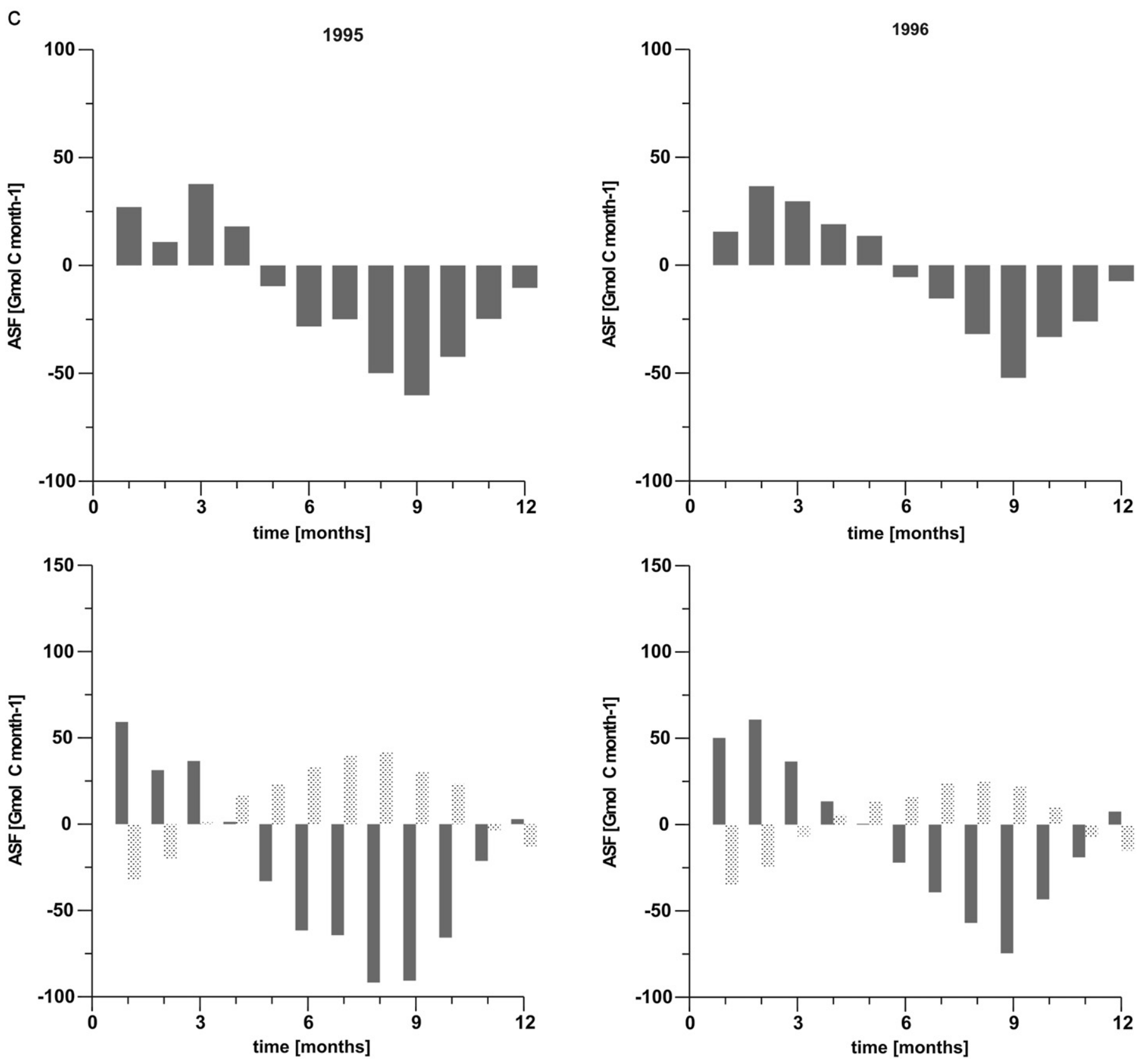

Fig. 5. (Continued)

have led to an increased decomposition of organic material in the deeper parts of the North Sea in 1996 compared to 1995. We tested this hypothesis by repeating the simulation for 1996 with the advective forcing fields of the year 1995. The result was that the HR decreased by only $40 \mathrm{Gmol} \mathrm{Cyr}^{-1}$, which did not explain the difference in HR between the two years in the standard run.

The number of days with a temperature difference of more than $0.5^{\circ} \mathrm{C}$ between 0 and $30 \mathrm{~m}$ for a northern station $\left(58.9^{\circ} \mathrm{N}\right.$, $0.6^{\circ} \mathrm{E}$ ) was significantly higher in 1995 than in 1996 (Table 2). Therefore we hypothesized in a next step that the strong increase of HR in 1996 was due to increased vertical mixing (Fig. 6). A simulation for the year 1996 with vertical diffusion coefficients of 1995 yielded a HR decline by $220 \mathrm{Gmol} \mathrm{C} \mathrm{yr}^{-1}$. This allows the conclusion that the weaker stratification (rather than advection)
Table 2

Comparison of northern North Sea features 1995 vs. 1996: net water outflow via the Norwegian Trench $\left(1 \mathrm{~Sv}=10^{6} \mathrm{~m}^{3} \mathrm{~s}^{-1}\right)$, net export of carbon, days with stratification (see text), heterotrophic respiration (HR), HR in 1996 when the water transport from 1995 is used, HR in 1996 when the water transports and the vertical eddy diffusion coefficients from 1995 are used.

\begin{tabular}{|c|c|c|}
\hline & 1995 & 1996 \\
\hline Norwegian Trench water outflow (Sv) & 1.60 & 1.52 \\
\hline 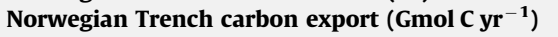 & 110,654 & 104,835 \\
\hline Days with stratification $(\Delta T>0.5 \mathrm{C})$ & 83 & 64 \\
\hline 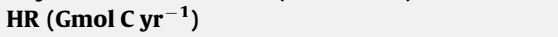 & 5750 & 6108 \\
\hline 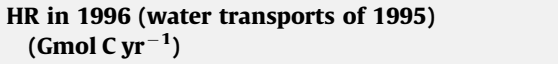 & & 6068 \\
\hline 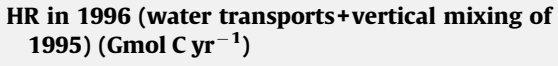 & & 5888 \\
\hline
\end{tabular}




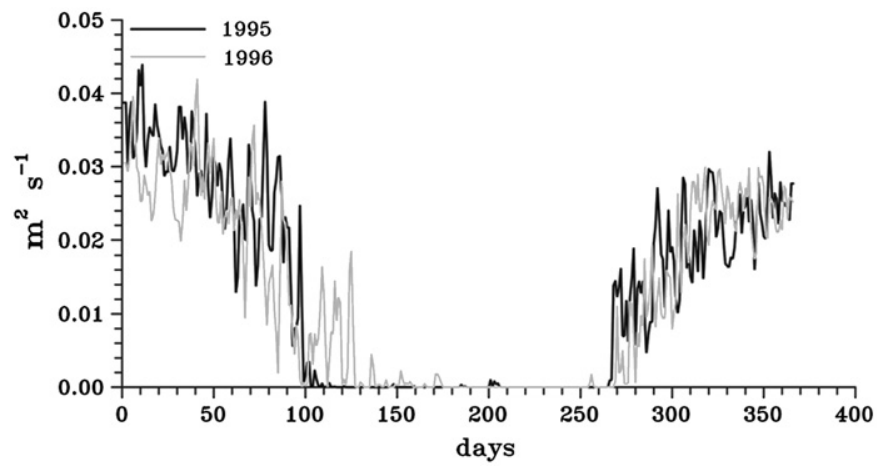

Fig. 6. Vertical mixing coefficients (in $\mathrm{m}^{2} \mathrm{~s}^{-1}$ ) at $30 \mathrm{~m}$ depth in the northern North Sea at $58.9^{\circ} \mathrm{N}, 0.6^{\circ} \mathrm{S}$ for the years 1995 and 1996 .

is responsible for the increase of HR from 1995 to 1996 in the standard run.

The annual North Sea-wide Redfield production $\mathrm{NPP}_{\text {red }}$ is similar in both years, with a substantial decline in the SNS in 1996 , compensated by a nearly equal increase in the NNS. The decline of NPP ( $\mathrm{NPP}_{\text {red }}$ as well as NPP exc $)$ in the SNS is mainly due to reduced nitrogen inputs by the rivers (PK1), partly also due to the lower temperatures during the first months of the year 1996. On the other hand, the increase of $\mathrm{NPP}_{\text {red }}$ in the NNS is a consequence of the weaker stratification, and thus a larger supply of nutrients by mixing from deeper layers during spring 1996 (Fig. 6). Correspondingly, the nitrogen depletion phase after the spring bloom which stimulates $\mathrm{NPP}_{\text {exc }}$ is shortened. In order to quantify the drivers of these opposing effects, we compared the surplus of riverine nitrogen input into the SNS in 1995 vs. 1996 (126 mmol N m$~^{-2} \mathrm{yr}^{-1}$ ) with the difference of DIN (1996-1995) imported into the upper layer via mixing at a relatively deep station ( $\left.130 \mathrm{~m} ; 58.9^{\circ} \mathrm{N}, 0.6^{\circ} \mathrm{S}\right)$ in the NNS $\left(247 \mathrm{mmol} \mathrm{N} \mathrm{m}^{-2} \mathrm{yr}^{-1}\right)$. Taking into account that the deep northern station is not representative for the whole NNS, we conclude that the differences of DIN input are in the same order of magnitude.

The seasonal (and interannual) variability of the different production fluxes can be seen in Fig. 7. Here, the depth-integrated monthly values of $\mathrm{NPP}_{\text {red }}$ (split into 'new', i.e. $\mathrm{NO}_{3}$-fuelled production $\mathrm{NPP}_{\text {new }}$, and 'regenerated', i.e. $\mathrm{NH}_{4}$-fuelled primary production $\mathrm{NPP}_{\text {reg }}$ ) and of $\mathrm{NPP}_{\text {exc }}$ are shown for the whole North Sea (Fig. 7a) as well as for both sub-regions (Fig. 7b and c) for the year 1995. For comparison, Fig. 7d shows the corresponding results for the whole North Sea and for the year 1996. While for the NNS (Fig. 7b) the maximum of the NPP red $_{\text {occurs during }}$ spring, in the SNS (Fig. 7c) this maximum is reached during the summer months. As can be seen, according to our model the $\mathrm{NPP}_{\text {exc }}$ seems to be relatively more important in the NNS due to the longer periods of nutrient depletion phases. This, however, is in contrast to the observation, that in the Southern Bight Phaeocystis spp. dominating the bloom produce carbon-rich mucus which is partly and slowly degradable (Schiettecatte et al., 2006; Alderkamp et al., 2007). Because Phaeocystis with its complex life cycle is not included in our model we might miss an important part of $\mathrm{NPP}_{\text {exc }}$ in that region. In May and June 1996, the $\mathrm{NPP}_{\text {red }}$ of the whole North Sea is somewhat higher than in 1995, with the consequence of less NPP exc during the same period. The highest values of $N_{\text {new }}$ are always reached in April, whereas $N_{\text {reg }}$ has its maximum in June/July. The mean $f$-ratios for the whole North Sea are 0.30 (1995) and 0.28 (1996), respectively.

\subsubsection{Carbon budgets}

The carbon budgets were calculated for the North Sea as a whole and for the two different sub-regions (SNS and NNS). The fluxes were separated into DIC and total organic carbon (TOC) fluxes. Fig. 8 shows these budgets for 1995 with emphasis on the trans-boundary fluxes, i.e. the fluxes across the boundaries to the North Atlantic and the Baltic, the fluxes across the interface with the atmosphere and the inflow via rivers. The internal biogeochemical fluxes given in Table 1 are here summarized as net ecosystem production: NEP $>0$ indicates a source of TOC and a sink of DIC and vice versa. $\triangle \mathrm{DIC}$ and $\triangle \mathrm{TOC}$ denote the internal accumulation/loss over the year.

For the whole North Sea (Fig. 8a) we obtained an NEP of

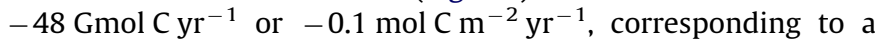
net-heterotrophic system. According to our results, the North Sea is divided into a strong net-heterotrophic NNS (Fig. 8b) and a netautotrophic SNS (Fig. 8c). Both areas exchange carbon across the section at $55.4^{\circ} \mathrm{N}$ (denoted as NI-55.4): the net transport of both the inorganic and the organic fraction is directed from south to north. The DIC flux is mainly fed by the Atlantic inflow through the English Channel (NI-south); in case of TOC only about half of the south-to-north flux enters via the Channel, another $29 \%$ are supplied by rivers. The total system (Fig. 8a) accumulates organic carbon partly due to the net import across the boundaries, while inorganic carbon is lost, mainly across the northern boundaries NW, NT, and SK (see Fig. 1) summarized as NI-north in Fig. 8b.

\section{Discussion}

\subsection{DIC and TALK}

The concentrations of DIC and their regional distribution depend critically on the boundary conditions prescribed, in particular at the open boundary to the North Atlantic and to the Baltic. Sensitivity studies showed that using DIC (and TALK) boundary conditions from climatological databases (CDIAC) induced too high levels of the simulated DIC concentrations. Thomas et al. (2008) demonstrated that the use of climatological DIC concentrations cannot be justified given the substantial interannual variability of DIC concentrations in the eastern temperate North Atlantic.

Assuming that TALK is subject to less interannual variations than, e.g. DIC, and to only weak long-term trends, we decided to use the alkalinity data obtained during the CANOBA project in $2001 / 2002$ for our simulation period 1995/1996. The effect of near-surface TALK increase due to nitrate assimilation and alkalinity decrease by degradation in lower layers may play a role for the vertical distribution of TALK in the stratified NNS. In principle, this effect is also included in the prescribed TALK fields, but its intensity and the consequences for the near-surface $\mathrm{pCO}_{2}$ may change from year to year. To test this we applied the model in a 1D version at a northern position with (a) prescribed TALK and (b) prognostic TALK. The resulting annual air-sea fluxes of $\mathrm{CO}_{2}$ differed by less than $4 \%$.

\subsection{Air-sea $\mathrm{CO}_{2}$ fluxes and carbon budgets}

According to our simulation, in 1996, the year with the extremely negative winter-time NAOI, the net-autotrophic state of the SNS is weaker than in 1995, whereas the net-heterotrophic state of the NNS is strengthened (Table 1), which results in a strengthening of the net-heterotrophic state of the North Sea as a whole in 1996 compared to 1995. As a consequence, the biologically driven air-sea fluxes of $\mathrm{CO}_{2}$ in both regions are larger in 1995 than in 1996. This is illustrated in Fig. 5, where the monthly air-sea fluxes of $\mathrm{CO}_{2}$ are given for both years. The comparison of the total $\mathrm{CO}_{2}$ flux (upper panels) with the $\mathrm{CO}_{2}$ 
a

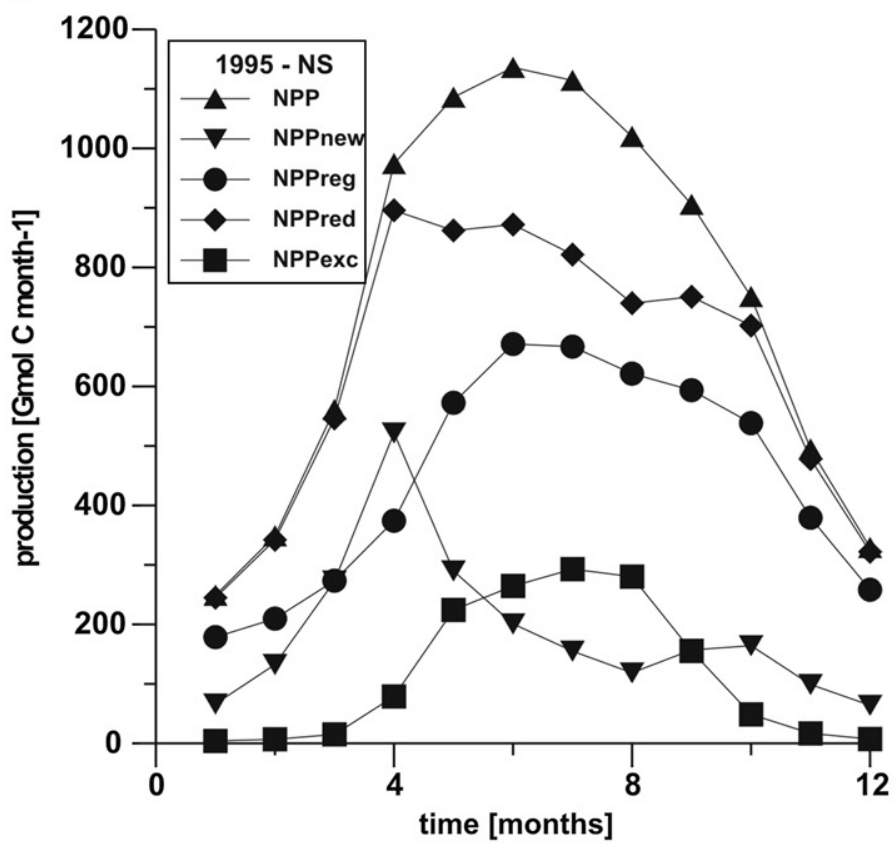

C

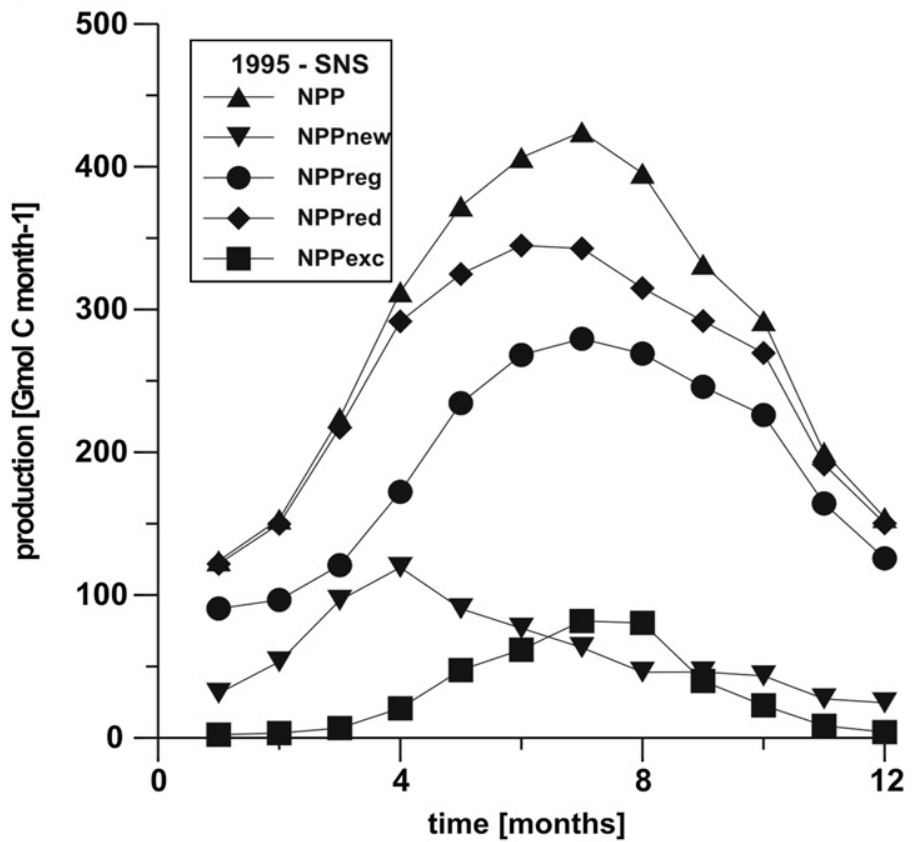

b

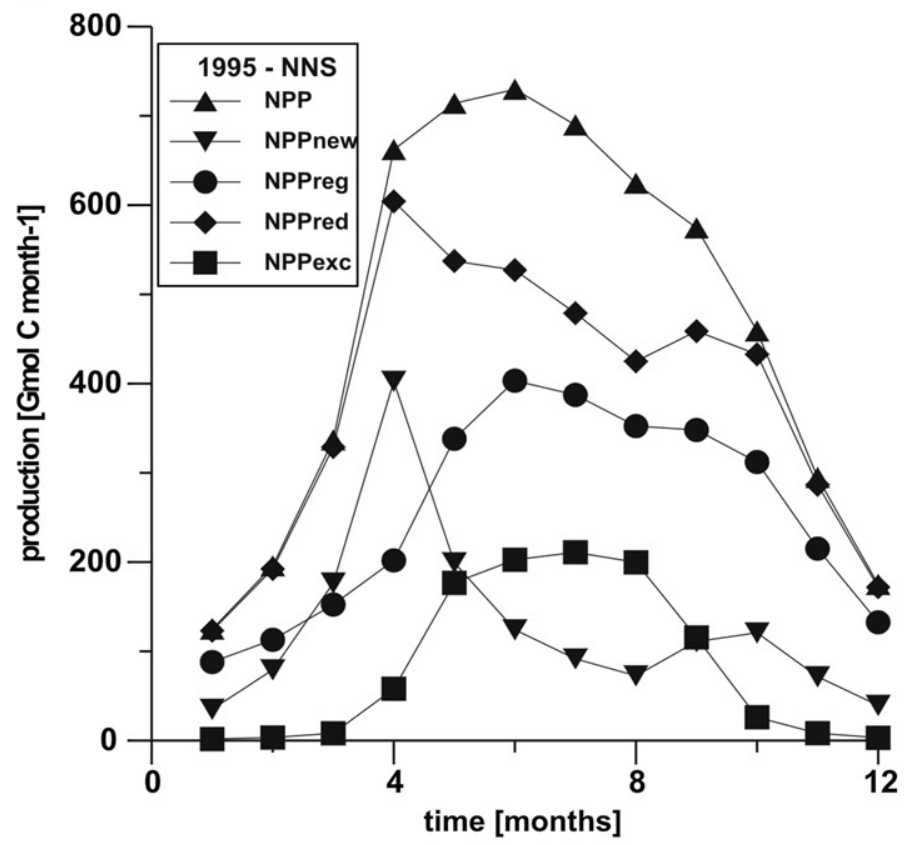

d

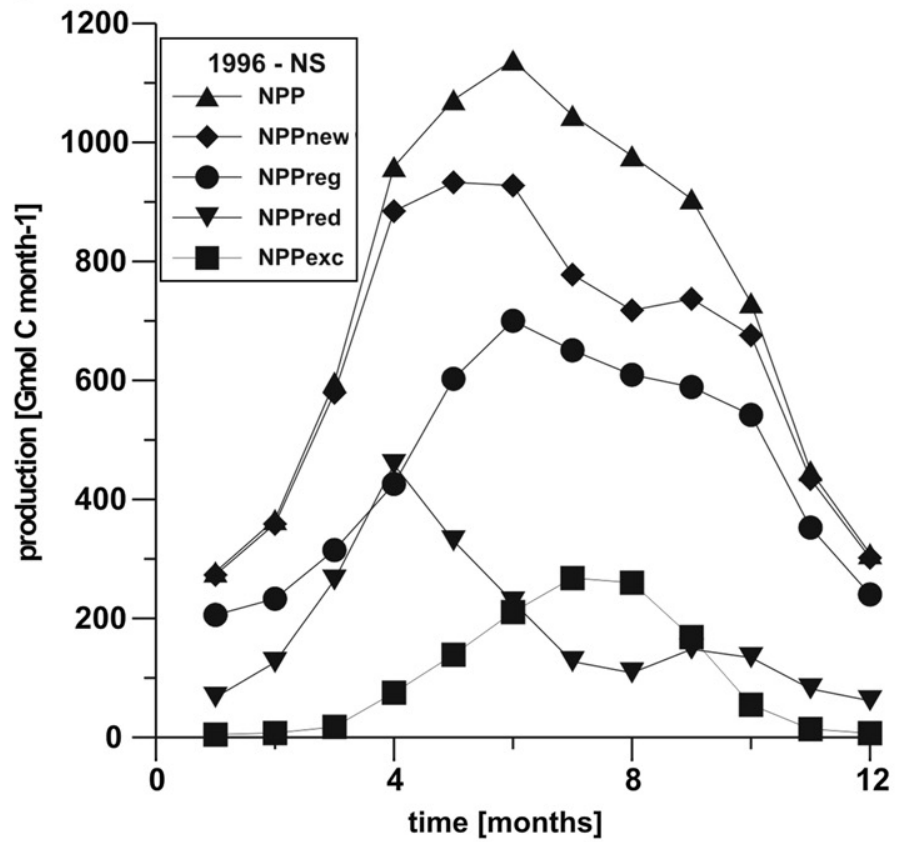

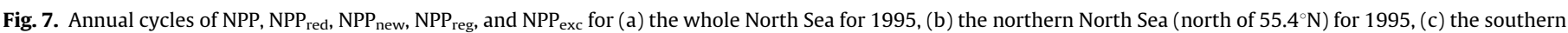
North Sea (south of $55.4^{\circ} \mathrm{N}$ ) for 1995, and (d) for the whole North Sea for 1996.

fluxes resolved according to the different drivers (lower panels) shows e.g., that the physics (i.e. the lower SST) rather than biological activity is responsible for the high $\mathrm{CO}_{2}$ uptake in particular during May and June 1996. While the physically driven $\mathrm{CO}_{2}$ flux changes direction from release to uptake, the biologically driven flux during these two months decreased in 1996 compared to 1995 . This is seemingly contradictory to the higher NPP in May and June 1996, but can be explained by a large upward transport of DIC due to the stronger vertical mixing in these months in 1996 (Fig. 6).

For the whole North Sea, Thomas et al. (2005b) calculated an NEP of $4.0 \mathrm{~mol} \mathrm{C} \mathrm{m}^{-2} \mathrm{yr}^{-1}$ for the upper $30 \mathrm{~m}$, while Bozec et al.
(2006) gave an improved estimate of $4.3 \mathrm{~mol} \mathrm{C} \mathrm{m}^{-2} \mathrm{yr}^{-1}$ by taking into account advection and turbulent mixing. For this depth-interval we obtained from our simulations an NEP of $6.2 \mathrm{~mol} \mathrm{C} \mathrm{m}^{-2} \mathrm{yr}^{-1}$ for 1995 , i.e. about $50 \%$ higher. When extending the calculation to the whole water column, Bozec et al. (2006) got an NEP value of $-0.1 \mathrm{~mol} \mathrm{C} \mathrm{m}^{-2} \mathrm{yr}^{-1}$, exactly the same value we got from our simulation for 1995.

The characterization of the SNS as weak net-autotrophic region coincides with other studies for the whole SNS (Bozec et al., 2006), or certain parts of it, as for the Southern Bight (Schiettecatte et al., 2007) and the Belgian Coastal Zone (Gypens et al., 2004). It differs from the study by Prowe et al. (2009) using the ECOHAM model 
a

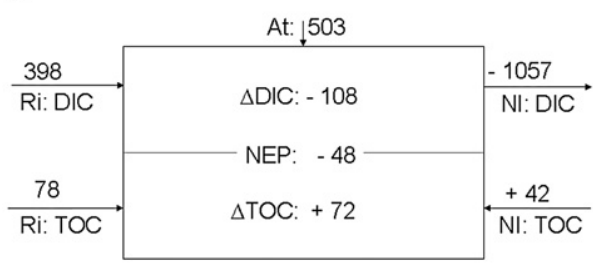

b

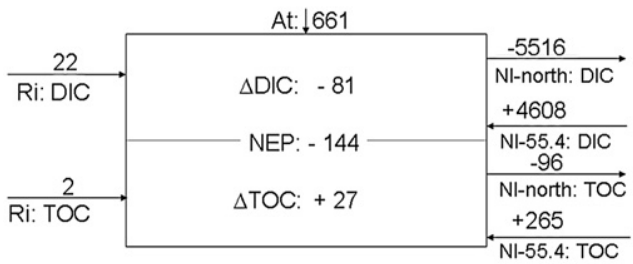

C

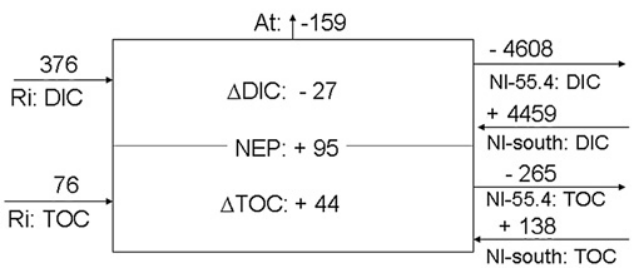

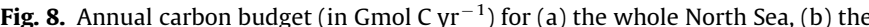
northern North Sea (NNS), and (c) the southern North Sea (SNS) for the year 1995. DIC - dissolved inorganic carbon, TOC - total organic carbon; At-exchange with the atmosphere, $\mathrm{Ri}$-riverine input, $\mathrm{NI}$-net import across outer boundaries; $\mathrm{NEP}$ - net ecosystem production. $\triangle \mathrm{DIN}$ and $\triangle \mathrm{TON}$ are the changes of content under the assumption of conservation of volume. NI-north-transport across sections NW, NT, and SK (see Fig. 1); NI-55.4-transport across the section at $55.4^{\circ} \mathrm{N}$; and NI-south-transport across section EC.

with $f_{\text {exc }}=0.0$ for the SNS. All mentioned papers find that the NEP as well as the air-sea flux of $\mathrm{CO}_{2}$ in the SNS varies around zero. For the Scheldt estuarine plume Borges et al. (2008) found large interannual variations of the NEP accompanied by $\mathrm{CO}_{2}$ outgassing of varying strength.

\subsection{Strength of excess production}

Fig. 9 shows the annual cycle in 1995 of simulated surface DIC concentrations for different choices of the strength of the excess production $\left(f_{\text {exc }}=0.0,0.5,1.0\right)$. Fig. 9a and b illustrates the behavior of off-shore areas in the northern and southern North Sea, respectively. The stars indicate observations in the corresponding area and time of the year, but for different years (Thomas et al., 2004). The lines give the daily averages over the (northern or southern) areas. In case of $f_{\text {exc }}=1.0$ (dotted line) we found a strong DIC drawdown, especially in summer. For $f_{\text {exc }}=0.0$ (dashed line) we obtained only a moderate summer DIC decrease. For $f_{\text {exc }}=0.5$ (full line) the summer concentrations fall between the two others. In winter (until day 120), the curves for $f_{\text {exc }}=0.0$ fall below those for the higher $f_{\text {exc. }}$. This is due to enhanced winter remineralization rates in case of (moderate or full) excess production. Even though the scatter of the observations is quite large, the spring and summer concentrations in the NNS support the choice of $f_{\text {exc }}=0.5$ (Fig. 9a). The annual cycle of simulated DIC in the SNS (Fig. 9b) is less pronounced, even for the full excess production $\left(f_{\mathrm{exc}}=1.0\right)$. It cannot be determined whether the moderate $\left(f_{\text {exc }}=0.5\right)$ or the strong $\left(f_{\text {exc }}=1.0\right)$ excess production results in DIC concentrations closer to the observations. Our choice of $f_{\text {exc }}=0.5$ in the standard run for the whole model area is a

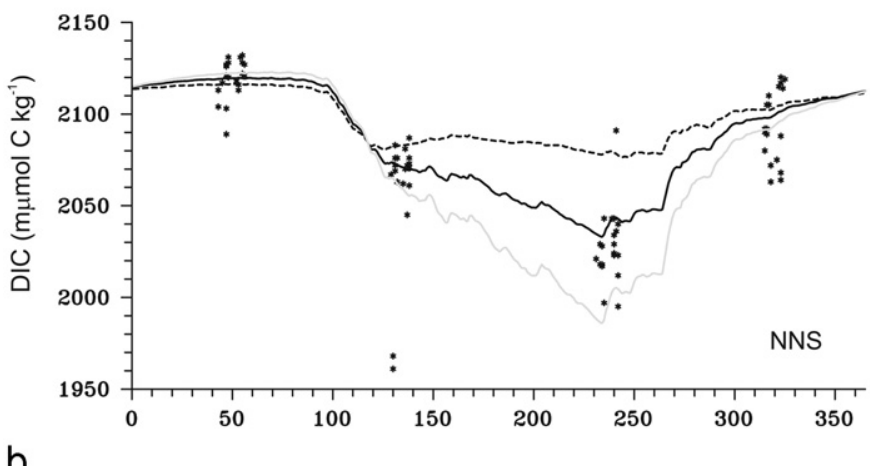

b

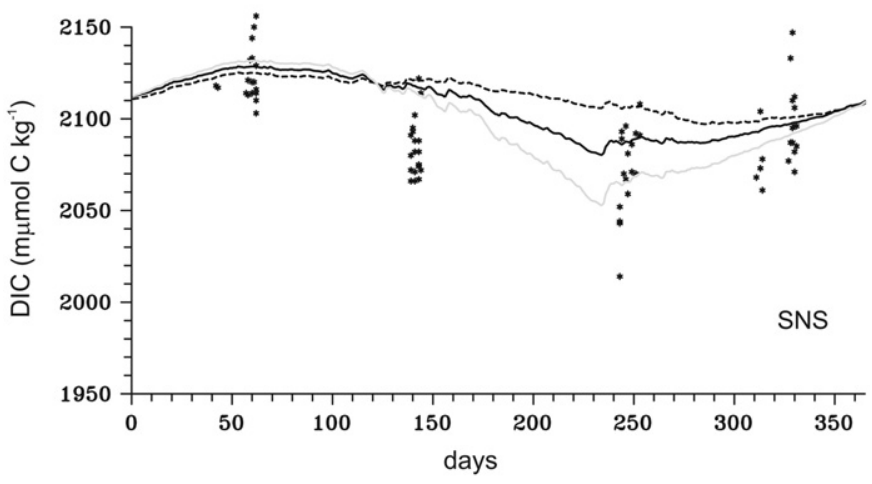

Fig. 9. Mean annual cycle of near-surface DIC concentrations (in $\mu \mathrm{mol} \mathrm{kg}^{-1}$ ) for off-shore areas in (a) the northern North Sea, (b) the southern North Sea for 3 different values of the parameter $f_{\text {exc }}$ : no excess production $\left(f_{\text {exc }}=0.0\right.$ - dashed line), maximum excess production $\left(f_{\text {exc }}=1.0\right.$-dotted line), and intermediate excess production $\left(f_{\text {exc }}=0.5\right.$-full line). The stars indicate observations in the corresponding area and time of the year (Thomas et al., 2004).

in contrast to an earlier modeling study (Prowe et al., 2009) where the DIC concentrations observed during 2001/2002 could best be reproduced by the simulations when different values of the parameter $f_{\text {exc }}$ were chosen for the SNS and the NNS. Primarily, our simpler and more straightforward approach was only successful thanks to the new boundary concentrations for DIC, which were lower than the climatological data used by Prowe et al. (2009). Besides, we were treating different years, when observations show considerable interannual variability in $\mathrm{pCO}_{2}$ values (e.g. Omar et al., 2010). Further work both on the observational and the modeling side is necessary to clarify the strength of excess production as well as the fate of the fixed organic carbon (Schartau et al., 2007).

As mentioned above, simulated spring DIC values exceed those of the observations in the SNS. One explanation for this deviation is the difference between the simulated SST for 1995 and corresponding observed values in 2002: While the observed SST in the southern (off-shore) region was about $12{ }^{\circ} \mathrm{C}$ during the second half of May, the simulated SST (in 1995) was below $9{ }^{\circ} \mathrm{C}$. As a higher SST raises the $\mathrm{pCO}_{2}$ of surface waters and thus the tendency for outgassing, lower DIC concentrations could be expected for 2002. Additionally, carbon fixation by biological production is amplified by higher temperature. But, likewise, an underestimation of the phytoplankton bloom, e.g. Phaeocystis, by the model is possible.

\section{Conclusions}

According to our simulations, in the mid-nineties the North Sea took up atmospheric $\mathrm{CO}_{2}$ and exported DIC into the North 
Atlantic. We could confirm the finding obtained by Thomas et al. (2005a) from extensive observations made in 2001/2002, according to which the North Sea acts as a carbon shelf pump. In the NNS, the simulated rate of $\mathrm{CO}_{2}$ uptake $\left(\sim 2 \mathrm{~mol} \mathrm{C} \mathrm{m}^{-2} \mathrm{yr}^{-1}\right)$ is comparable with the estimates from observations in the North Atlantic at corresponding latitudes (Takahashi et al., 2002). One should realize, however, that the North Sea is additionally loaded by riverine carbon. Without the biologically mediated uptake in the surface waters the North Sea would become a (weak) source for atmospheric $\mathrm{CO}_{2}$.

The sensitivity studies concerning the impact of NAO-driven variations of advection vs. vertical diffusion on the North Sea system indicate that the local meteorological dynamics (partly determined by the NAO) have a stronger impact than the variations in water exchange between the North Atlantic and the North Sea, at least for interannual variations. We conclude this from our sensitivity experiments (Table 2 ), where we successively exchanged hydrodynamic features from one year to another: Firstly we exchanged the advection and secondly the vertical eddy diffusion coefficients. The latter change had a much larger impact on the biogeochemical fluxes than the first one.

From our results future perspectives for the impact of climate change onto the carbon pump mechanism can be delineated: stronger stratification may induce a stronger $\mathrm{CO}_{2}$ pump mechanism. On the other hand, a decrease of $\mathrm{pH}$ due to continuous $\mathrm{CO}_{2}$ uptake from the atmosphere will weaken the $\mathrm{CO}_{2}$ pump mechanism (Thomas et al., 2007).

To investigate the latter effect, repeated measurements of DIC, $\mathrm{pCO}_{2}$, etc. are planned. These investigations will be accompanied by improved model simulations, e.g. with explicit inclusion of calcifying phytoplankton and of Phaeocystis, prognostic calculation of TALK with realistic boundary values at the Wadden Sea coast, reasonable TALK river loads and enlargement of the model area, to better represent the transports across the shelf edge.

\section{Acknowledgments}

We would like to thank our colleagues from the Max-PlanckInstitute for Meteorology Hamburg, Uwe Mikolajewicz, Jochen Segschneider and Ernst Maier-Reimer for supplying us with the open ocean boundary conditions. We are grateful to Andreas Moll and Hermann Lenhart for useful hints and to Elizabeth Shadwick for proofreading the manuscript. The critical comments of two anonymous reviewers helped improve the manuscript.

This work contributes to CARBOOCEAN (EU-FP6) and IGBP/ IHDP LOICZ. AVB is a research associate at the Fonds National de la Recherche Scientifique.

\section{References}

Abril, G., Nogueira, E., Hetcheber, H., Cabeçadas, G., Lemaire, E., Brogueira, M.J., 2002. Behaviour of organic carbon in nine contrasting European estuaries. Estuarine, Coastal and Shelf Science 54, 241-262.

Alderkamp, A.-C., Buma, G.J., Van Rijssel, M., 2007. The carbohydrates of Phaeocystis and their degradation in the microbial food web. Biogeochemistry 83, 99-118.

Borges, A.V., Frankignoulle, M., 1999. Daily and seasonal variations of the partial pressure of $\mathrm{CO}_{2}$ in surface seawater along Belgian and southern Dutch coastal areas. Journal of Marine Systems 19 (4), 251-266.

Borges, A.V., Frankignoulle, M., 2002. Distribution and air-water exchange of carbon-dioxide in the Scheldt plume off the Belgian coast. Biogeochemistry 59, 41-67.

Borges, A.V., Frankignoulle, M., 2003. Distribution of surface carbon dioxide and air-sea exchange in the English Channel and adjacent areas. Journal of Geophysical Research 198 (C5), 1-14. doi:10.1029/JC000571.

Borges, A.V., Ruddick, K., Schiettecatte, L.-S., Delille, B., 2008. Net ecosystem production and carbon dioxide fluxes in the Scheldt estuarine plume. BMC Ecology 8 (15), 10. doi:10.1186/1472-6785-8-15.
Borges, A.V., Gypens, N., 2010. Carbonate chemistry in the coastal zone responds more strongly to eutrophication than to ocean acidification. Limnology and Oceanography 55, 346-353.

Bozec, Y., Thomas, H., Elkalay, K., de Baar, H.J.W., 2005. The continental shelf pump for $\mathrm{CO}_{2}$ in the North Sea-evidence from summer observation. Marine Chemistry 93, 131-147.

Bozec, Y., Thomas, H., Schiettecatte, L.-S., Borges, A.V., Elkalay, K., de Baar, H.J.W., 2006. Assessment of the processes controlling seasonal variations of dissolved inorganic carbon in the North Sea. Limnology and Oceanography 51 (6), 2746-2762.

Chung, S.-N., Lee, K., Feely, R.A., Sabine, C.L., Millero, F.J., Wanninkhof, R., Bullister, J.L., Key, R.M., Peng, T.-H., 2003. Calcium carbonate budget in the Atlantic Ocean based on water column inorganic carbon chemistry. Global Biogeochemical Cycles 17 (4), 1093.

Conkright, M.E., Locarnini, R.A., Garcia, H.E., O’Brien, T.D., Boyer, T.P., Stephens, C., Antonov, J.I., 2002. World Ocean Atlas 2001: Objective Analyses, Data Statistics, and Figures. CD-ROM Documentation, National Oceanographic Data Center, Silver Spring, MD 17 pp.

Dickson, A.G., Millero, F.J., 1987. A comparison of the equilibrium constants for the dissociation of carbonic acid in seawater media. Deep-Sea Research 34 (10), 1733-1743.

Dippner, J.W., 1997. SST anomalies in the North Sea in relation to the North Atlantic Oscillation and the influence on the theoretical spawning time of fish. Deutsche Hydrographische Zeitschrift 49 (2/3), 267-275.

Engel, A., 2002. Direct relationship between $\mathrm{CO}_{2}$ uptake and transparent exopolymer particles production in natural phytoplankton. Journal of Plankton Research 24, 49-53.

Fogg, G.E., 1983. The ecological significance of extracellular products of phytoplankton photosynthesis. Botanica Marina 26, 3-14.

Frankignoulle, M., Borges, A.V., 2001. European continental shelf as a significant sink for atmospheric carbon dioxide. Global Biogeochemical Cycles 15, 569-576.

Frankignoulle, M., Elskens, M., Biondo, R., Bourge, I., Canon, C., Desgam, S., Dauby, P., 1996. Distribution of inorganic carbon and related parameters in surface seawater of the English Channel in spring 1994. Journal of Marine Systems 7 (2-4), 427-434.

Gypens, N., Lancelot, C., Borges, A.V., 2004. Carbon dynamics and $\mathrm{CO}_{2}$ air-sea exchanges in the eutrophied coastal waters of the Southern Bight of the North Sea: a modelling study. Biogeosciences 1, 147-157.

Gypens, N., Borges, A.V., Lancelot, C., 2009. Effect of eutrophication on air-sea $\mathrm{CO}_{2}$ fluxes in the coastal Southern North Sea: a model study of the past 50 years. Global Change Biology 15, 1040-1056.

Hoppema, J.M.J., 1991. The seasonal behaviour of carbon dioxide and oxygen in the coastal North Sea along the Netherlands. Netherlands Journal of Sea Research $28,167-179$.

Kalnay, E., Kanamitsu, M., Kistler, R., Collins, W., Deaven, D., Gandin, L., Iredell, M., Saha, S., White, G., Woollen, J., Zhu, Y., Chelliah, M., Ebisuzaki, W., Higgins, W., Janowiak, J., Ropelewski, C., Mo, K.C., Wang, J., Leetmaa, A., Reynolds, R., Jenne, R., Joseph, D., 1996. The NCEP/NCAR 40-year reanalysis project. Bulletin of the American Meteorological Society 77, 437-470.

Kempe, S., Pegler, K., 1991. Sinks and sources of $\mathrm{CO}_{2}$ in coastal seas: the North Sea. Tellus 43B, 224-235.

Langer, M.R., 2008. Assessing the contribution of foraminiferan protists to global ocean carbonate production. The Journal of Eukaryotic Microbiology 55 (3), 163-169.

Loewe, P., 1996. Surface temperatures of the North Sea in 1996. Deutsche Hydrographische Zeitschrift 48 (2), 175-184.

Maier-Reimer, E., 1993. Geochemical cycles in an ocean general circulation model: preindustrial tracer distributions. Global Biogeochemical Cycles 7, 645-677.

Maier-Reimer, E., Kriest, I., Segschneider J., Wetzel, P., 2005. The Hamburg Ocean Carbon Cycle Model HAMOCC5.1-Technical Description Release 1.1. Berichte zur Erdsystemforschung 14/2005, Max-Planck-Institut für Meteorologie, Hamburg, Germany (Available at 〈www.mpimet.mpg.de〉).

Marsland, S.J., Haak, H., Jungclaus, J.H., Latif, M., Röske, F., 2003. The global ocean/ sea ice model with orthogonal curvilinear coordinates. Ocean Modelling 5 (2), 91-127.

Mehrbach, C., Culberson, C.H., Hawley, J.E., Pytkowicz, R.M., 1973. Measurement of the apparent dissociation constant of carbonic acid in sea-water at atmospheric pressure. Limnology and Oceanography 18, 897-907.

Nightingale, P.D., Maline, G., Law, C.S., Watson, A.J., Liss, P.S., Liddicoat, M.I., Boutin, J., Upstill-Goddard, R.C., 2000. In-situ evaluation of air-sea gas exchange parameterizations using novel conservative and volatile tracers. Global Biogeochemical Cycles 14, 373-387.

Omar, A.M., Olsen, A., Johannessen, T., Hoppema, M., Thomas, H., Borges, A.V., 2010. Spatiotemporal variations of $\mathrm{fCO}_{2}$ in the North Sea. Ocean Science 6, 77-89.

Pätsch, J., Kühn, W., Radach, G., Santana Casiano, J.M., Gonzalez Davila, M., Neuer, S., Freudenthal, T., Llinas, O., 2002. Interannual variability of carbon fluxes at the North Atlantic Station ESTOC. Deep-Sea Research (Part II) 49, 253-288.

Pätsch, J., Kühn, W., 2008. Nitrogen and carbon cycling in the North Sea and exchange with the North Atlantic-a model study. Part I. Nitrogen budget and fluxes. Continental Shelf Research 28, 767-787.

Pegler, K., Kempe, S., 1988. The carbonate system of the North Sea: determination of alkalinity and $\mathrm{TCO}_{2}$ and calculation of $\mathrm{PCO}_{2}$ and $\mathrm{SI}_{\text {cal }}$ (spring 1986). 
1716

W. Kühn et al. / Continental Shelf Research 30 (2010) 1701-1716

Mitteilungen des Geologisch-Paläontologischen Instituts der Universität Hamburg, 35-87.

Prowe, A.E.F., Thomas, H., Pätsch, J., Kühn, W., Bozec, Y., Schiettecatte, L.-S., Borges, A.V., de Baar, H.J.W., 2009. Mechanisms controlling the air-sea $\mathrm{CO}_{2}$ flux in the North Sea. Continental Shelf Research 29, 1801-1808.

Radach, G., Pätsch, J., 2007. Variability of continental riverine freshwater and nutrient inputs into the North Sea for the years 1977-2000 and its consequences for the assessment of eutrophication. Estuaries and Coasts 30 (1), 66-81.

Raymond, P.A., Bauer, J.E., 2000. Bacterial consumption of DOC during transport through a temperate estuary. Aquatic Microbial Ecology 22, 1-12.

RWS., 1992. Guidance Document for the NSTF modelling workshop, 6-8 May, 1992, Den Haag, Directoraat Generaal Rijkswaterstaat, 41 pp.

Schartau, M., Engel, A., Schröter, J., Thoms, S., Völker, C., Wolf-Gladrow, D., 2007. Modelling carbon overconsumption and the formation of extracellular particulate organic carbon. Biogeosciences 4, 422-454.

Schiettecatte, L.-S., Gazeau, F., Van der Zee, C., Brion, N., Borges, A.V., 2006. Time series of the partial pressure of carbon dioxide (2001-2004) and preliminary inorganic carbon budget in the Scheldt plume (Belgian coastal waters). Geochemistry, Geophysics, Geosystems 7, Q06009. doi:10.1029/2005GC001161.

Schiettecatte, L.-S., Thomas, H., Bozec, Y., Borges, A.V., 2007. High temporal coverage of carbon dioxide measurements in the Southern Bight of the North Sea. Marine Chemistry 106 (1-2), 161-173.

Takahashi, T., Sutherland, S.C., Sweeney, C., Poisson, A., Metzl, N., Tilbrook, B., Bates, N., Wanninkhof, R., Feely, R.A., Sabine, C., Olafsson, J., Nojiri, Y., 2002. Global seaair $\mathrm{CO}_{2}$ flux based on climatological surface ocean $\mathrm{pCO}_{2}$, and seasonal biological and temperature effects. Deep-Sea Research 49, 1601-1622.

Thomas, H., Ittekot, V., Osterroht, Ch., Schneider, B., 1999. Preferential recycling of nutrients - the ocean's way to increase new production and to pass nutrient limitation? Limnology and Oceanography 44, 1999-2004.
Thomas, H., Bozec, Y., Elkalay, K., de Baar, H.J.W., 2004. Enhanced open ocean storage of $\mathrm{CO}_{2}$ from shelf sea pumping. Science 104, 1005-1008.

Thomas, H., Bozec, Y., de Baar, H.J.W., Elkalay, K., Frankignoulle, M., Schiettecatte, L.-S., Kattner, G., Borges, A.V., 2005a. The carbon budget of the North Sea. Biogeosciences 2, 87-96.

Thomas, H., Bozec, Y., Elkalay, K., de Baar, H.J.W., Borges, A.V., Schiettecatte, L.-S., $2005 \mathrm{~b}$. Controls of the surface water partial pressure of $\mathrm{CO}_{2}$ in the North Sea. Biogeosciences 2 (4), 323-334.

Thomas, H., Prowe, A.E.F., van Heuven, S., Bozec, Y., de Baar, H.J.W., Schiettecatte, L.-S., Suykens, K., Kone, M., Borges, A.V., Lima, I.D., Doney, S.C., 2007. Rapid decline of the $\mathrm{CO}_{2}$ buffering capacity in the North Sea and implications for the North Atlantic Ocean. Global Biogeochemical Cycles 21, GB4001 doi:10.1029/ 2006 GB002825.

Thomas, H., Prowe, A.E.F., Lima, I.D., Doney, S.C., Wanninkhof, R., Greatbatch, R.J., Schuster, U., Corbière, A., 2008. Changes in the North Atlantic Oscillation influence $\mathrm{CO}_{2}$ uptake in the North Atlantic over the past 2 decades. Global Biogeochemical Cycles 22, GB4027. doi:10.1029/2007GB003167.

Toggweiler, J.R., 1993. Carbon overconsumption. Nature 363, 210-211.

Tsunogai, S., Watanabe, S., Sato, T., 1999. Is there a "continental shelf pump" for the absorption of atmospheric $\mathrm{CO}_{2}$ ? Tellus 51, 701-712.

Wanninkhof, R., 1992. Relationship between wind speed and gas exchange over the ocean. Journal of Geophysical Research 97 (C5), 7373-7382.

Wanninkhof, R., McGillis, W.R., 1999. A cubic relationship between air-sea $\mathrm{CO}_{2}$ exchange and wind speed. Geophysical Research Letters 26 (13), 1889-1892.

Wiegner, T.N., Seitzinger, S.P., 2001. Photochemical and microbial degradation of external dissolved organic matter inputs to rivers. Aquatic Microbial Ecology 24, 27-40. 